\title{
Source Identification and Fish Exposure for Polychlorinated Biphenyls Using Congener Analysis from Passive Water Samplers in the Millers River Basin, Massachusetts
}

Water-Resources Investigations Report 00-4250

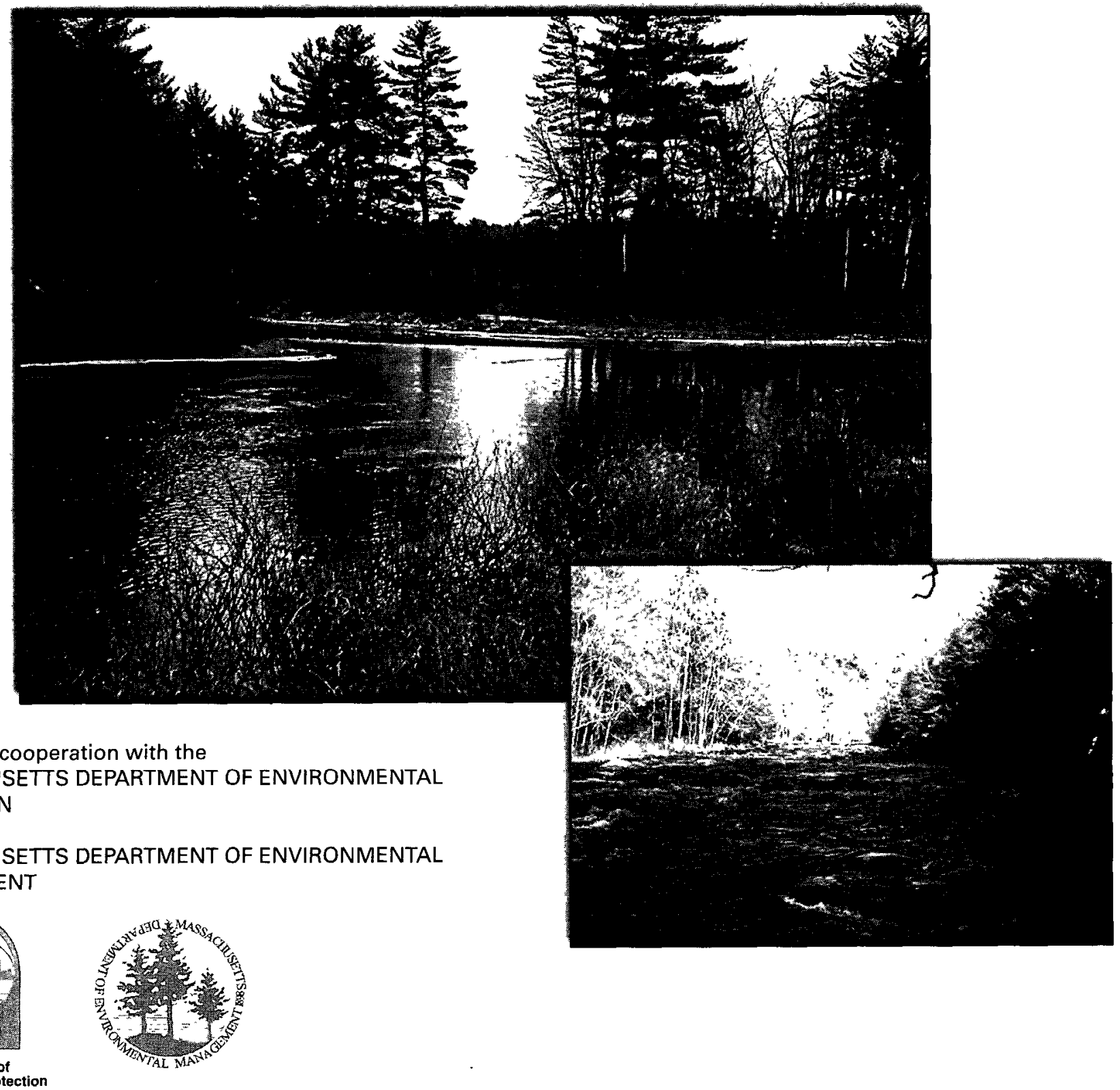

Prepared in cooperation with the

MASSACHUSETTS DEPARTMENT OF ENVIRONMENTAL

PROTECTION

and the

MASSACHUSETTS DEPARTMENT OF ENVIRONMENTAL MANAGEMENT

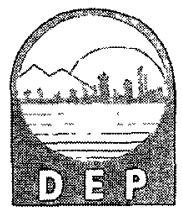

Department of Environmental Protection

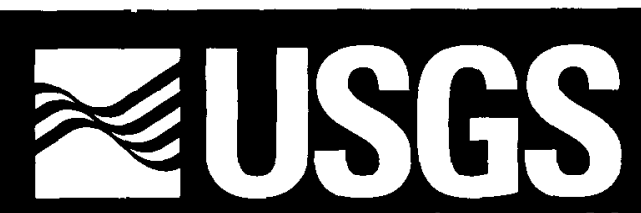




\section{Cover photos:}

Upper photo shows the confluence of the Millers River and the Otter River in the low-gradient reach upstream from the Birch Hill Dam taken $12 / 6 / 00$ by John A. Colman. The other, taken $12 / 18 / 00$ is the Millers River in the steep-gradient reach one mile downstream from the USGS surface-water discharge station at South Royalston, Massachusetts (01164000). Photo by Britt Stock. 
U.S. Department of the Interior

U.S. Geological Survey

\section{Source Identification and Fish Exposure for Polychlorinated Biphenyls Using Congener Analysis from Passive Water Samplers in the Millers River Basin, Massachusetts}

By JOHN A. COLMAN

Water-Resources Investigations Report 00-4250

Prepared in cooperation with the

MASSACHUSETTS DEPARTMENT OF ENVIRONMENTAL PROTECTION and the MASSACHUSETTS DEPARTMENT OF ENVIRONMENTAL MANAGEMENT

Northborough, Massachusetts 


\section{U.S. DEPARTMENT OF THE INTERIOR}

GALE A. NORTON, Secretary

U.S. GEOLOGICAL SURVEY

Charles G. Groat, Director

The use of trade or product names in this report is for identification purposes only and does not constitute endorsement by the U.S. Government.

For additional information write to:

Chief, Massachusetts-Rhode Island District

U.S. Geological Survey

Water Resources Division

10 Bearfoot Road

Northborough, MA 01532

or visit our web site at

http://ma.water.usgs.gov
Copies of this report can be purchased from:

U.S. Geological Survey

Branch of Information Services

Box 25286

Denver, CO 80225-0286 


\section{CONTENTS}

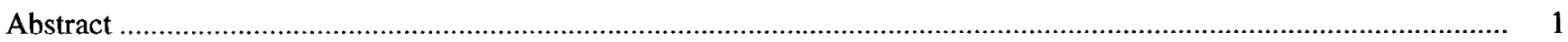

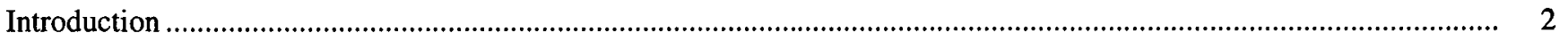

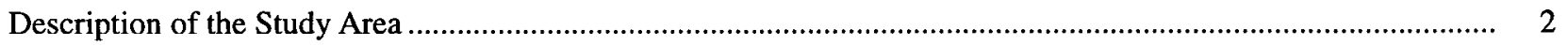

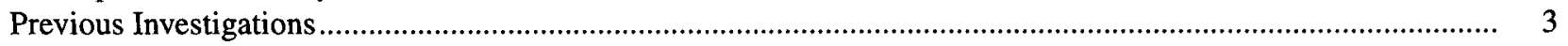

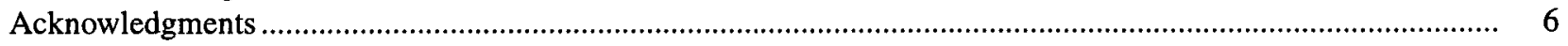

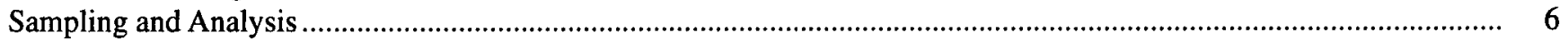

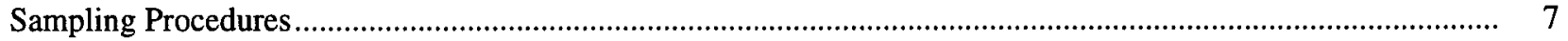

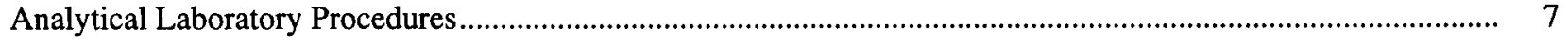

Statistics for Evaluating Changes in Congener Patterns ......................................................................... 10

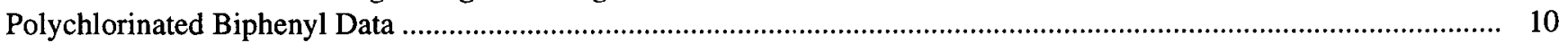

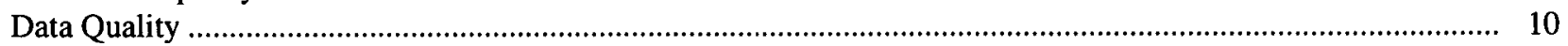

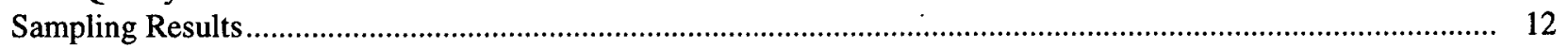

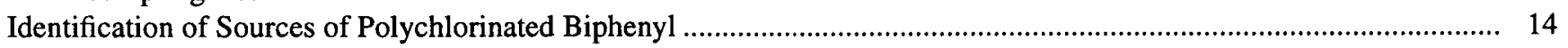

Sources Upstream from Birch Hill Dam .............................................................................................. 15

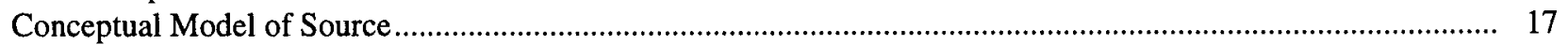

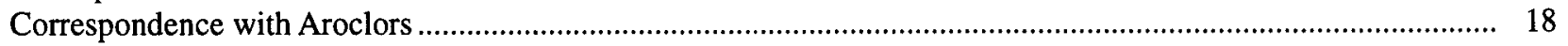

Congener Pattern Weathering and Sources Downstream from Birch Hill Dam ............................................. 18

Exposure of Fish to Polychlorinated Biphenyls in the Millers River Basin...........................................................21

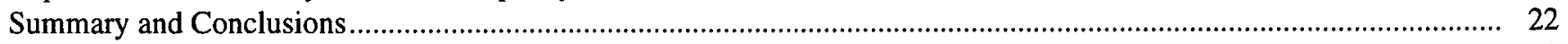

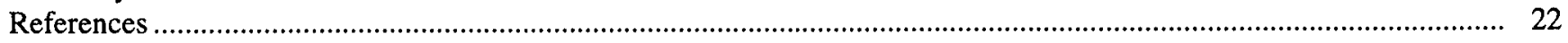

Appendix A. Polychlorinated biphenyl congener names and International Union of Pure and Applied

Chemistry (IUPAC) numbers in gas-chromatograph domain order ........................................................... 25

Appendix B. Polychlorinated biphenyl congeners from 31 stations in the Millers River Basin, Massachusetts ................ 29

\section{FIGURES}

1. Map showing Millers River Basin in Massachusetts and New Hampshire with town boundaries, town centers, and PCB passive-sampler stations displayed

2, 3. Graphs showing:

2. Correspondence of RMSD with mean $\Sigma$ PCB concentration for duplicate samples from the Millers River Basin

3. Differences in congener patterns in duplicate samples ................................................................ 11

4. Hydrographs showing daily mean discharge data for USGS stream gaging stations at Otter River at Otter River (station number 01 163200), Millers River at South Royalston (station number 0116400), and Millers River at Erving (station number 01166500).

5-8. Graphs showing:

5. (A) Streambed elevation profile of the Millers River from the Connecticut River to the confluence with the Otter River and of the Otter River to its source and $(B) \Sigma P C B$ and between-station RMSD of congener concentrations in downstream order on the Otter River and the Millers River.

6. PCB congener patterns in the Otter River ... 16

7. Relative PCB concentration congener patterns compared, average of three samples from station O-31.2 with patterns of Aroclor 1016 and 1242 .

8. Ratio comparisons of normalized PCB congener concentrations ................................................... 20 


\section{TABLES}

1. Stations sampled for PCBs using passive samplers in the Millers River and Otter River, Massachusetts, during 1999

2. Analyte ions monitored, surrogates used, and RRF determination for polychlorinated biphenyl Aroclors by HRGC/LRMS

3. Sums of congeners, Aroclor mixtures from passive samplers, and computed water-column concentrations at stations on the Millers River and the Otter River.

CONVERSION FACTORS, VERTICAL DATUM, AND ABBREVIATIONS

CONVERSION FACTORS

\begin{tabular}{|c|c|c|}
\hline Multiply & By & To obtain \\
\hline inch (in.) & 25.4 & millimeter \\
\hline foot $(\mathrm{ft})$ & 0.3048 & meter \\
\hline quart (qt) & 0.6636 & liter \\
\hline mile (mi) & 1.609 & kilometer \\
\hline square mile $\left(\mathrm{mi}^{2}\right)$ & 2.590 & square kilometer \\
\hline foot per mile $(\mathrm{ft} / \mathrm{mi})$ & 0.1894 & meter per kilometer \\
\hline cubic foot per second $\left(\mathrm{ft}^{3} / \mathrm{s}\right)$ & 0.02832 & cubic meter per second \\
\hline \multicolumn{3}{|c|}{$\begin{array}{l}\text { Temperature is given in degrees Celsius }\left({ }^{\circ} \mathrm{C}\right) \text {, which can be converted to } \\
\text { degrees Fahrenheit }\left({ }^{\circ} \mathrm{F}\right) \text { by use of the following equation: } \\
\qquad{ }^{\circ} \mathrm{F}=1.8\left({ }^{\circ} \mathrm{C}\right)+32\end{array}$} \\
\hline
\end{tabular}

\section{VERTICAL DATUM}

Sea level: In this report, "sea level" refers to the National Geodetic Vertical Datum of 1929 (NGVD of 1929) - a geodetic datum derived from a general adjustment of the first-order level nets of the United States and Canada, formerly called Sea Level Datum of 1929.

\section{ABBREVIATIONS}

Abbreviated concentration units used in this report: Chemical concentrations in water solution are given in nanograms per liter ( $\mathrm{ng} / \mathrm{L}$ ). Chemical concentrations in hexane solution are given in nanograms per hexane sample. One nanogram per liter is equivalent to one billionth of a gram per liter. Chemical concentration in fish tissue and sediment is given in micrograms per gram $(\mu \mathrm{g} / \mathrm{g})$. One microgram per gram is equivalent to one millionth of a gram of chemical per gram of fish (or sediment). These concentrations are on a wet-weight basis for fish and a dry-weight basis for sediment. 


\title{
Source Identification and Fish Exposure for Polychlorinated Biphenyls Using Congener Analysis from Passive Water Samplers in the Millers River Basin, Massachusetts
}

\author{
By John A. Colman
}

\section{Abstract}

Measurements of elevated concentrations of polychlorinated biphenyls (PCBs) in fish and in streambed sediments of the Millers River Basin, Massachusetts and New Hampshire, have been reported without evidence of the PCB source. In 1999 , an investigation was initiated to determine the source(s) of the elevated PCB concentrations observed in fish and to establish the cxtent of fish exposure to PCBs along the entire main stems of the Millers River and one of its tributaries the Otter River.

Passive samplers deployed for 2-week intervals in the water-column at 31 stations, during summer and fall 1999, were used to assess PCB concentrations in the Millers River Basin. The samplers concentrate PCBs, which diffuse from the water column through a polyethylene membrane to hexane ( 0.200 liters) contained inside the samplers. Only dissolved PCBs (likely equivalent to the bioavailable fraction) are subject to diffusion through the membrane. The summed concentrations of all targeted PCB congeners ( $\mathrm{PPCB}$ ) retrieved from the samplers ranged from 1 to 8,000 nanograms per hexane sample. Concentration and congener-pattern comparisons indicated that the historical release of PCBs in the Millers River Basin likely occurred on the Otter River at the upstream margin of Baldwinville, Mass. Elevated water-column concentrations measured in a wetland reach on the Otter River downstream from
Baldwinville were compatible with a conceptual model for a present-day (1999) source in streambed sediments, to which the PCBs partitioned after their original introduction into the Otter River and from which PCBs are released to the water now that the original discharge has ceased or greatly decreased.

Two four-fold decreases in $\Sigma$ PCB concentrations in the Millers River, by comparison with the highest concentration on the Otter River, likely were caused by (1) dilution with water from the relatively uncontaminated upstream Millers River and (2) volatilization of PCBs from the Millers River in steep-gradient reaches. A relatively constant concentration of $\Sigma$ PCBs in the reach of the Millers River from river mile 20 to river mile 10 was likely a consequence of a balance between decreased volatilization rates in that relatively low-gradient reach and resupply of PCBs to the water column from contaminated streambed sediments. A second high-gradient reach from river mile 10 to the confluence of the Millers River with the Connecticut River also was associated with a decrease in concentration of water-column $\Sigma$ PCBs. Volatilization as a loss mechanism was supported by evidence in the form of slight changes of the congener pattern in the reaches where decreases occurred.

Exposure of fish food webs to concentrations of dissolved PCBs exceeded the U.S. Environmental Protection Agency's water-quality criterion for PCBs throughout most of the Millers 
River and Otter River main stems. Because the apparent source of PCBs discharged was upstream on the Otter River, a large number of river miles downstream (more than $30 \mathrm{mi}$ ) had summer watercolumn PCB concentrations that would likely lead to high concentrations of PCBs in fish.

\section{INTRODUCTION}

In 1985, elevated concentrations of polychlorinated biphenyls (PCBs) were reported for fish tissue samples collected from the Millers River downstream from the U.S. Army Corps of Engineers (USACE) Birch Hill Dam by the Massachusetts Division of Water Pollution Control (MDWPC). Subsequent studies by the MDWPC and the USACE confirmed initial findings (U.S. Army Corps of Engineers, 1993) and reported elevated concentrations of PCBs in streambed sediments and over-bank deposits along the Otter River in the wetlands upstream from the Birch Hill Dam (U.S. Army Corps of Engineers, 1995). Repeated measurements of PCBs in fish at concentrations above limits for fish consumption advisories $(2 \mu \mathrm{g} / \mathrm{g}$ wetweight basis), as well as in sediments at high concentrations, are concerns of the public as determined by public meetings of the Massachusetts Executive Office of Environmental Affairs Millers River Watershed Team. Thus, a priority for the Millers River Watershed Team is to determine when and where PCBs were introduced and how pervasive exposure of fish to PCBs might be in the Millers River Basin.

In March 1999, a water-column investigation was initiated by the U.S. Geological Survey (USGS), in cooperation with the Massachusetts Department of Environmental Protection and the Massachusetts Department of Environmental Management, to determine the source(s) of the elevated PCB concentrations observed in fish and to establish the extent of fish exposure to PCBs along the entire main stem of the Millers River and of one of its tributaries, the Otter River. The USGS investigation of PCBs in the water column was complemented by a USACE study of water, fish, and sediment in the Birch Hill Dam area and by a U.S. Environmental Protection Agency (USEPA) on-site study at facilities bordering the Otter River. The water-column sampling employed passive samplers that respond to the dissolved fraction of PCBs, a fraction that is bioavailable for concentration through aquatic food webs. Reported here are the
USGS results of comparisons among 31 sites of total PCBs and PCB-congener patterns that were used to assess sources of PCBs and exposure of fish to PCBs in the Millers River Basin.

\section{Description of the Study Area}

The Millers River drains a total area of about $390 \mathrm{mi}^{2}$ in Massachusetts and New Hampshire, of which $313 \mathrm{mi}^{2}$ are in Massachusetts (fig. 1). The drainage basin is about 78 percent forested, 11 percent open land, 8 percent wetland, and 3 percent urban areas. Many wetlands in the basin indicate areas of former shallow lakes and ponds that have gradually filled through sedimentation. There are a total of 107 lakes and ponds in the basin. Seventy-two of these lakes are 10 acres or more in area. Lake Monomonac, northeast of Winchendon, Mass. (592 acres), is the only lake larger than 500 acres in the watershed (Massachusetts Department of Environmental Management, Division of Water Resources, 1978; Massachusetts Department of Environmental Quality Engineering, Division of Water Pollution Control, 1976).

The Millers River formed late in the last glacial period when several glacial lakes in the region coalesced and drained into the Connecticut River. The headwaters of the Millers River are in southern New Hampshire, in the towns of Fitzwilliam and Rindge, and in north-central Massachusetts, in the towns of Ashburnham and Winchendon. The North Branch and the main stem of the river join in Winchendon and then flow westward to the Connecticut River. Major tributaries of the Millers River are the Otter River, entering the Millers River in Winchendon, and the Tully River, entering the Millers River in Athol; both tributaries flow primarily through wetlands. The USACE Birch Hill Dam, located just downstream from the confluence of the Otter River with the Millers River, regulates a pool of 3,200 acres when full. Under normal flow conditions, water is not held back at the dam and the streams behind the dam are within their banks, which are bordered by extensive wetlands.

Overall, the Millers River has a moderate gradient, averaging about $18 \mathrm{ft} / \mathrm{mi}$ from its headwaters area to the USGS streamflow-gaging station at Erving, Mass., a distance of about 43 river miles (Massachusetts Division of Water Pollution Control, 1980). However, a 5-mile reach of the Millers River that flows through a wooded area between South Royalston 
and Athol, Mass. has an average gradient of about $43 \mathrm{ft} / \mathrm{mi}$, which is about five times the average for rivers in Massachusetts (Massachusetts Department of Environmental Quality Engineering, Division of Water Pollution Control, 1974). Downstream from Athol, the stream gradient is almost flat in the reach extending to Orange, Mass. Downstream from Orange, the gradient gradually increases to Millers Falls, Mass., finally equaling the gradient of the Royalston-Athol reach. The gradient of the Otter River averages about $18 \mathrm{ft} / \mathrm{mi}$ for a distance of about 11.5 river mile; the steepest gradient occurs between Templeton, Mass., town center and Trout Brook (Wandle, 1984).

\section{Previous Investigations}

PCBs were first measured at elevated concentrations in fish from the Millers River through the Massachusetts Fish Toxics Monitoring Program. In 1985, fish were collected at five locations for PCB analysis in response to a high concentration measured earlier (1972) in one white sucker (Catostomus commersoni) from the Millers River. Samples were split and sent to two laboratories, the Mississippi State Chemical Laboratory available through the U.S. Fish and Wildlife Service, and the Massachusetts State Lawrence Experiment Station, resulting in two complete sets of data that corresponded well. Species collected varied among sites, but white suckers were obtained at four sites. Total PCBs determined in wholefish white sucker composites were 2.0, 0.79, 4.2 and $0.2 \mu \mathrm{g} / \mathrm{g}$ (all concentrations in fish are in micrograms PCB per gram of fish, wet weight) for stations at river mile 7.45, 17.8, 28.4 and 39.5, respectively. (Approximate river mile, determined as distance upstream from the confluence of the Millers River and the Connecticut River, can be ascertained from the numbers associated with stations shown in fig. 1). At these stations and at an additional station at river mile 1.8 , concentrations were variable in other species collected, including American eel (Anguilla rostrata), fallfish (Semotilus corporalis), chain pickerel (Esox niger), and smallmouth bass (Micropterus dolomieu). The highest concentration of PCBs measured, $5.8 \mu \mathrm{g} / \mathrm{g}$, was in a composite American eel sample, which also had the highest lipid content (11 percent). Concentrations were low in all species measured at the most upstream station (river mile 39.5) $-0.20 \mu \mathrm{g} / \mathrm{g}, 0.18 \mu \mathrm{g} / \mathrm{g}$, and not detected, in fallfish, white sucker, and chain pickerel, respectively (Robert Maietta, Massachusetts Department of Water Pollution Control, written commun., 1988).

In 1987, more fish were sampled, and sediments also were included in a cooperative investigation by the MDWPC and USACE (U.S. Army Corps of Engineers, 1993, 1995). All fish were analyzed at the Massachusetts State Lawrence Experiment Station. PCB concentrations in fish fillets and whole fish composites from three stations on the Millers River upstream from the Otter River confluence (river mile $34.9,38.4$ and 40 ) were all below $0.5 \mu \mathrm{g} / \mathrm{g}$, except for one yellow bullhead (Ameiurus natalis) from river mile 34.9; in which the concentration was $0.99 \mu \mathrm{g} / \mathrm{g}$. Concentrations of the PCBs measured in 5 different species collected from the Otter River, upstream from Baldwinville (river mile 36.7), were also relatively low $(<0.12$ to 0.88 , median $0.25 \mu \mathrm{g} / \mathrm{g}$ ). Six sites were investigated beginning $5 \mathrm{mi}$ downstream from the Birch Hill Dam and continuing downstream to 7.4 mi upstream of the confluence with the Connecticut River. In composites of white sucker fillets, which were collected at all stations but one, concentrations were highest nearest Birch Hill Dam, $(2.2 \mu \mathrm{g} / \mathrm{g}$, river mile 24.6), decreased through the next two stations downstream (river mile $21.1,14.1$ ), to $1.1 \mu \mathrm{g} / \mathrm{g}$ (river mile 10.9), and then increased to $1.6 \mu \mathrm{g} / \mathrm{g}$ at the most downstream station (river mile 7.4). The highest concentration of PCBs measured in the investigation, $5.5 \mu \mathrm{g} / \mathrm{g}$, was that in a brown trout fillet collected at river mile 8.4. A large range in concentrations, from less than 0.1 to $5.5 \mu \mathrm{g} / \mathrm{g}$, was measured in brown trout fillets. This variation may have been a result of the sampled fish consisting of a combination of recently stocked, presumably PCBfree, and longer resident fish, which had time to accumulate PCBs (Robert Maietta, oral commun., 2000).

Total concentrations of PCBs in sediments collected during the 1987 investigation were highest at stations between the Birch Hill Dam and the confluence with the Otter River (river mile 29.5 and 30.7), ranging from 4 to $49 \mu \mathrm{g} / \mathrm{g}$, dry-weight basis. All PCB concentrations in sediments are reported in micrograms PCBs per gram sediment, dry weight. At six stations downstream from the dam (river mile 0.1, 1.8, 10.9, $19.3,28.0,29.5)$ PCB concentrations in the sediments were less than detection limits of 0.1 to $0.5 \mu \mathrm{g} / \mathrm{g}$, except for station 10.9 , where concentrations in the two samples collected were 1.7 and $7.3 \mu \mathrm{g} / \mathrm{g}$, respectively. 


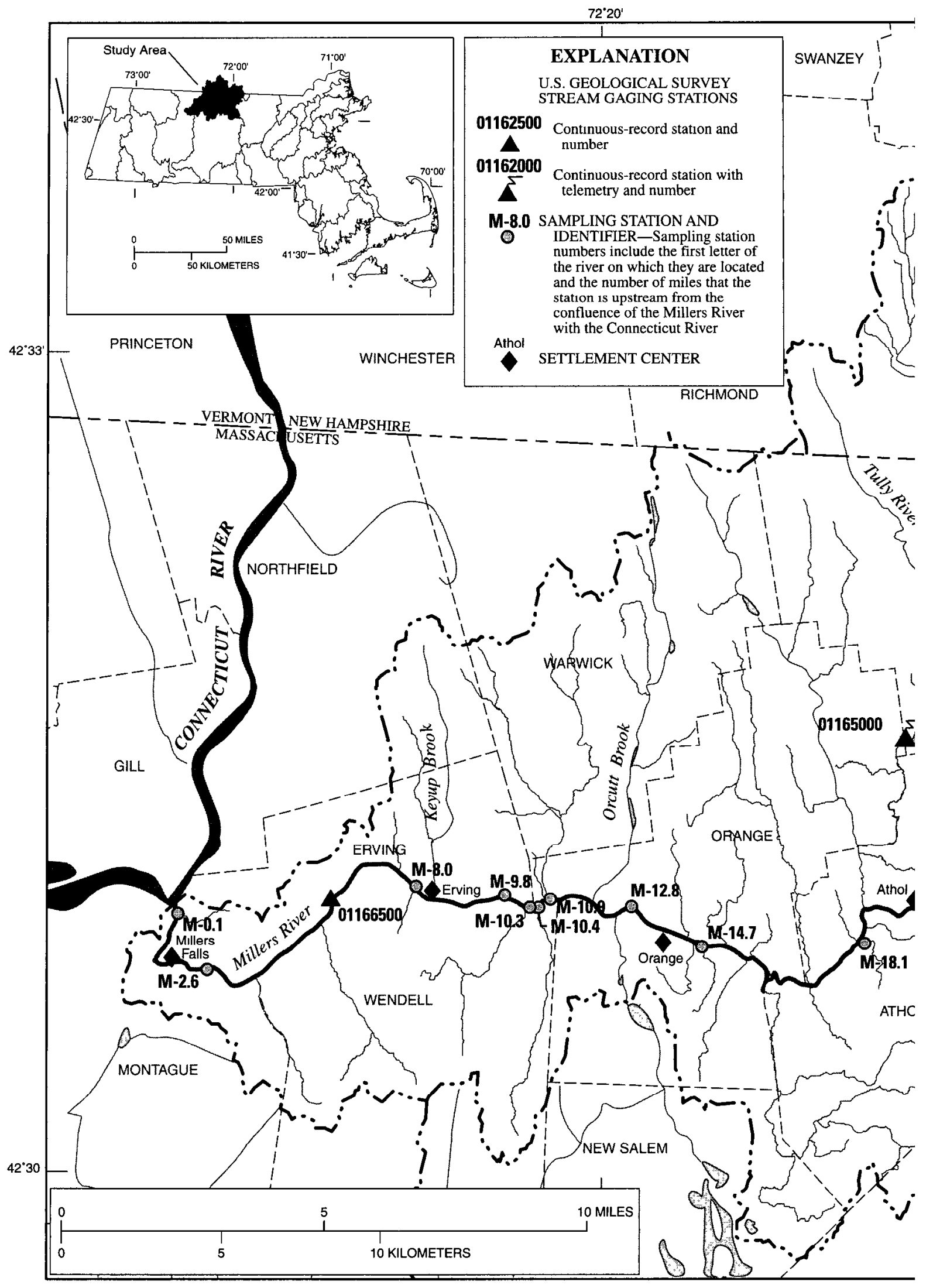

Figure 1. Millers River Basin in Massachusetts and New Hampshire with ton 


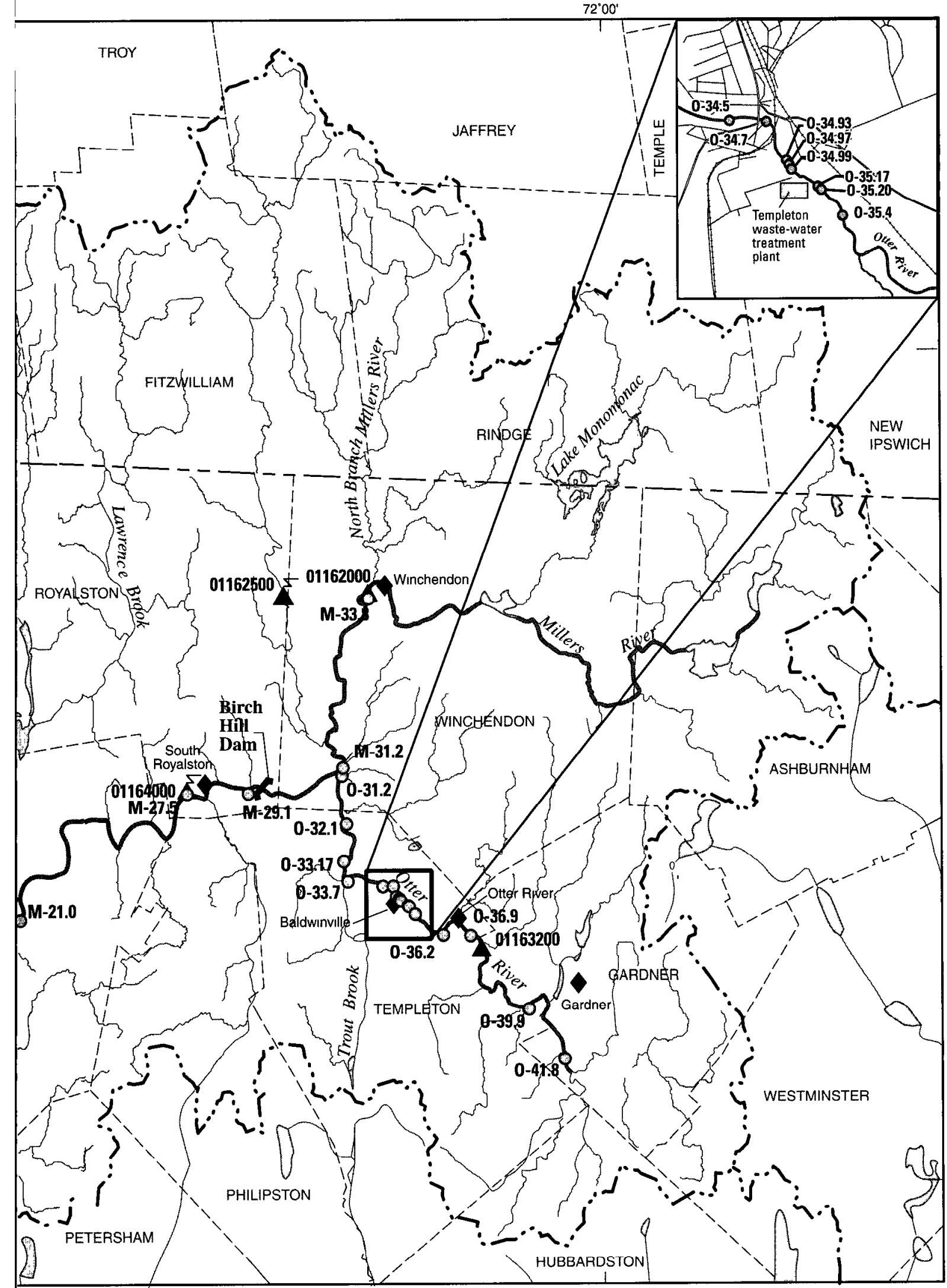

boundaries, town centers, and PCB passive-sampler stations displayed. 
In 1988, 16 more sediment samples were collected by USACE and MDWPC at various sediment depths in the Birch Hill Dam retention basin area. The highest PCB concentrations $(180 \mu \mathrm{g} / \mathrm{g})$ were measured in subsurface sediment ( 12 in. below the sedimentwater interface) at river mile 30.1 as well as in a subsediment layer (13.5 in. depth) at river mile 29.8 between the dam and the confluence of the Millers River with the Otter River. Concentrations of $250 \mu \mathrm{g} / \mathrm{g}$ were measured in subsurface sediment (14 in. deep) at a site on the Otter River (river mile 32.4). Low PCB concentrations (less than $0.5 \mu \mathrm{g} / \mathrm{g}$ ) were measured in sediment of the Millers River upstream from the Otter River confluence and in the Otter River upstream from Baldwinville.

Subsequent investigations were conducted in 1989,1990 , and 1991 to determine within-site variability of the sediment analysis and to measure PCB concentrations in fish samples from the apparently contaminated reach upstream from the dam and in the Otter River downstream from Baldwinville. These investigations indicated that high concentrations of PCBs were not always measured in sediments sampled repeatedly at the same locations, but that high concentrations (14 to $58 \mu \mathrm{g} / \mathrm{g}$ ) continued to be measured in these reaches. High PCB concentrations (as high as $29 \mu \mathrm{g} / \mathrm{g}$ ) also were measured in overbank sediment locations where frequency of flooding was high (U.S. Army Corps of Engineers 1991,1993, 1995).

PCB concentrations in fish fillets from the reach between the dam and downstream reaches of the Otter River ranged from 0.1 to $1.0 \mu \mathrm{g} / \mathrm{g}$, not as high as those measured downstream from the dam (U.S. Army Corps of Engineers, 1991,1993, 1995). No trout, which had the highest PCB concentrations elsewhere, were collected in this reach.

A regional investigation of organochlorines that included a Millers River Basin sample was published by Coles (1998). A PCB concentration of $0.58 \mu \mathrm{g} / \mathrm{g}$ was measured in a whole-fish composite white sucker sample collected in 1994 from the Otter River at the town center of Otter River (fig. 1).

\section{Acknowledgments}

The support of Alice Rojko, Millers River Basin team leader, Massachusetts Executive Office of Environmental Affairs, during planning and implementation of this investigation, is greatly appreciated. Simon
Litten of the New York Department of Environmental Protection and John Hassett of the State University of New York-Syracuse provided valuable assistance in project design and sampling techniques.

\section{SAMPLING AND ANALYSIS}

The major objectives of this investigation were (1) to determine the source(s) of the elevated PCB concentrations observed in fish and (2) to establish the extent of fish exposure to PCBs along the entire main stem of the Millers River and of a tributary the Otter River. PCB concentrations were measured by means of passive samplers suspended in the water column at intervals along the Millers River and the Otter River. PISCES samplers were used, as described in detail by Litten and others (1993). The samplers, each containing $0.200 \mathrm{~L}$ of hexane and fitted with a polyethylene membrane, absorb PCBs during a 2-week deployment interval. (All hexane and acetone used in the project was pesticide analysis grade). This deployment interval results in PCB concentrations in hexane that reflect time-integrated dissolved concentrations of PCBs in river water passing the sampling point (Litten and others, 1993).

Sampling of the water column rather than streambed sediment, another integrator of PCB concentrations, was selected because (1) water column samples generally require less laboratory-analysis cleanup than do sediment samples, so that detection limits are lower; (2) water-column results can give a better indication of PCB bioavailability, because dissolved PCBs cross cell membranes and are likely to get into the food web (Barron, 1990); and (3) water-column results are not subject to variability associated with sediments of grain size and organic carbon content. Passive samplers were chosen over grab-sample extraction because of (1) time integration of ambient PCB concentrations that occurs during sampler deployment, (2) ease of field deployment, and (3) sensitivity of the method (Litten and others, 1993). Hexane samplers were chosen over synthetic lipid-filled samplers (Rantalainen and others, 1998) to avoid extraction of PCBs from lipid and the additional laboratory cleanup necessary before analysis.

An additional design feature of this project was quantification of PCBs in terms of congeners, the individual PCB compounds, of which about 100 (of a possible 209) have been detected in environmental 
samples (Schulz and others, 1989). The different PCB congeners result from the various numbers and positions of chlorine atoms possible that can attach to a biphenyl ring structure. Aroclors (with distinguishing numbers of $1016,1232,1242,1254$, etc.) are mixtures of PCB congeners that were produced commercially, which in some combination of environmental introduction and biogeochemical weathering, account for the congener pattern present in stream samples. Because relative concentrations of PCB congeners are unlikely to be exactly the same in samples from different sources, changes in congener pattern within a river reach can indicate new sources of PCBs (Litten and others, 1993).

\section{Sampling Procedures}

Sampling procedures followed the methods of Litten and others (1993). Samplers were cleaned in the laboratory with soap and water, a deionized water rinse, and air drying, followed by one acetone rinse and three hexane rinses. Low density polyethylene membranes (cut from Ziploc bags) and Viton O-rings were cleaned by 7-hour soxhlet extraction with hexane. Membranes were always new; O-rings were re-used after soap and water cleaning and four solvent rinses (as for samplers). After cleaning, the samplers were assembled and wrapped in hexane-rinsed aluminum foil. In the field, the assembled samplers were hexanerinsed just prior to deployment to remove any contamination associated with storage or transport. Finally, samplers were filled with $0.200 \mathrm{~L}$ of hexane and installed in the stream. The passive samplers were hung 6 in. below the stream surface, membranes down, in pairs from plastic bottle buoys attached by nylon cord to cinder-block anchors. Sampling station locations were selected in pools, rather than in riffles, because slowly moving water was conducive to successful sampling.

Samplers were deployed during four intervals in the spring through fall, 1999 (table 1). Deployments usually were for 14 days, although at 5 sampling stations in May and 4 stations in November, deployments were for 13 days. So that the relative positions of the stations could be determined easily, they were numbered by river mile preceded by the first letter of the river on which they were located. For example, O-31.2 refers to the station on the Otter River $31.2 \mathrm{mi}$ upstream from the confluence of the Millers River with the Connecticut River. The upper Millers River and the Otter River were sampled first (May-June) followed by the lower Millers River (July). Two follow-up samplings were conducted, primarily of Otter River stations (August-September and November). The station nearest Birch Hill Dam (M-29.1) was sampled four times, once during each deployment. Sampling stations were located upstream and downstream from settlement centers on the rivers to bracket potential sources, at intervals ranging from 0.6 to $6 \mathrm{mi}$ initially and as close as $0.02 \mathrm{mi}$ in follow-up samplings (fig. 1).

Hydrographs of streamflow during the period of deployment were used to assess whether samplers remained suspended in the water column (not resting on the sediments) during the entire 2 weeks. Upon retrieval, samples were poured into $0.25 \mathrm{~L}$ precleaned I-Chem jars, and stored at $-20^{\circ} \mathrm{C}$ until shipment by overnight courier to the analytical laboratory, Axys Analytical Services, Ltd., in Sidney, British Columbia, Canada.

\section{Analytical Laboratory Procedures}

Samples received at the laboratory were transferred to secure storage and maintained in the dark at $4^{\circ} \mathrm{C}$ until preparation for analysis. The volume of each sample was determined using a graduated cylinder. Samples were prepared and analyzed for congeners using a modification of USEPA Method 8082A (U.S. Environmental Protection Agency, 1998). Principal modification of the technique was in means of detection/quantification, which was by lowresolution quadrupole mass selective detection, rather than by gas chromatography with electron-capture detection (ECD) and confirmation by mass spectrometer. A second modification was the use of carbon-13 labeled PCB congeners for the surrogate and internal standards, whereas Method 8082A uses ECD standards-unlabeled PCB 209 and tetrachloro-meta-xylene.

Samples were analyzed in batches of 10 to 12 that included a procedural blank. Each hexane sample was spiked with an aliquot of a standard solution of five surrogate carbon-13 labeled PCBs, International Union of Pure and Applied Chemistry (IUPAC) congener numbers 101, 105, 118, 180, and 209 , and dried over anhydrous sodium sulfate. 
Table 1. Stations sampled for PCBs using passive samplers in the Millers River and Otter River, Massachusetts during 1999

[Latitude and longitude are in degrees, minutes, and scconds; dates are month-day-ycar. No., number; USGS, U.S. Geological Survey]

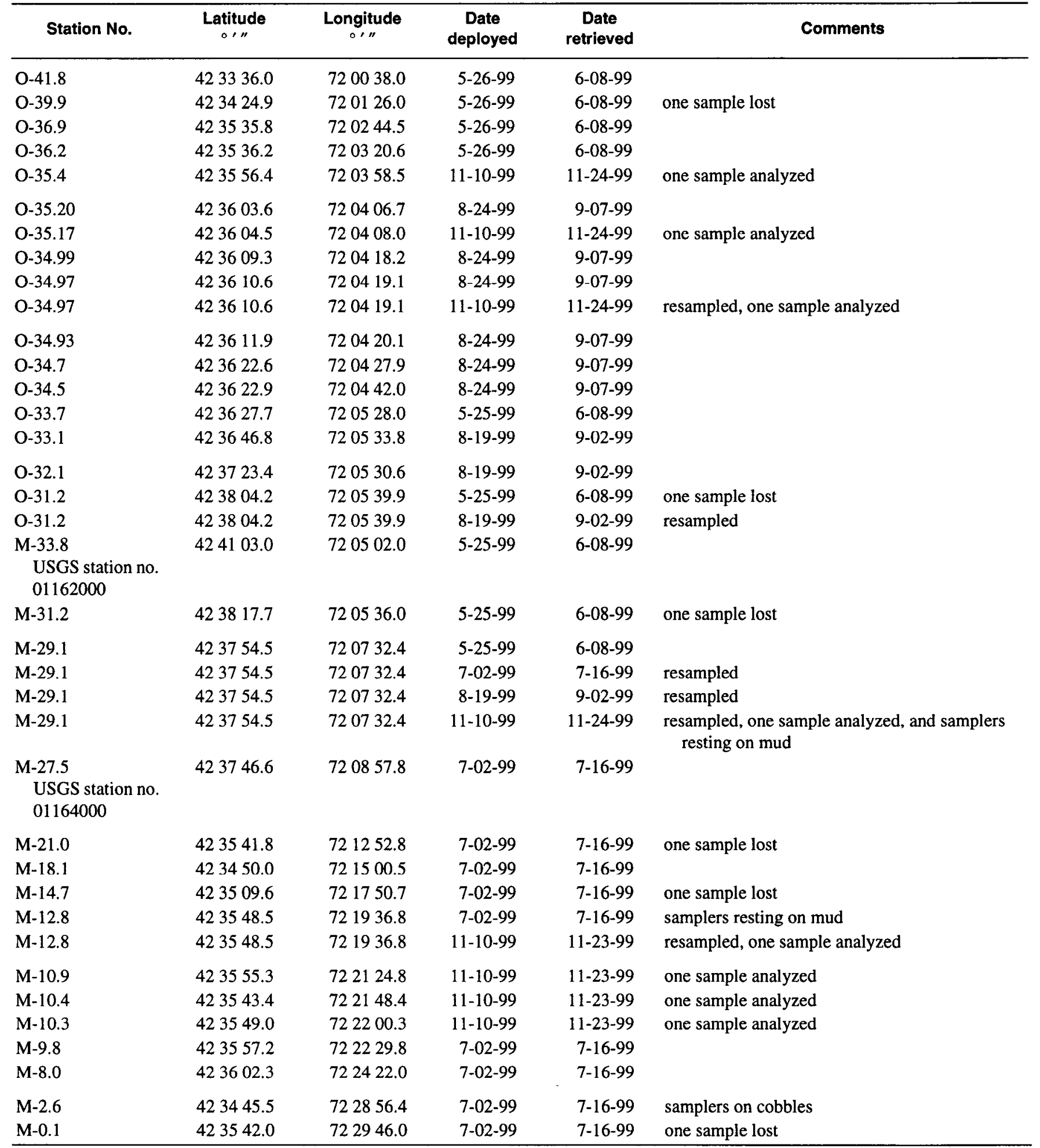


The dried extract was split gravimetrically; one half was reserved as backup sample, the other half was cleaned up on a Florisil column. After loading with the sample, the Florisil column was eluted with hexane followed by 15:85 dichloromethane:hexane. The latter fraction was treated with activated copper to remove sulfur, concentrated to a small volume, and transferred to an auto-sampler vial. Carbon-13 PCB 153 was added to the vial as a recovery (internal) standard.

High-resolution gas chromatography/lowresolution mass spectrometry analysis of the extract was carried out on a Finnigan Incos 50 mass spectrometer (MS) equipped with a Varian 3400 gas chromatograph, a CTC auto-sampler and a Prolab/Envirolink data system for MS control and data acquisition. A J\&W DB-5 capillary column (60 m, $0.25 \mathrm{~mm}$ i.d., 0.10 micron film thickness) was coupled directly to the MS source. The MS was operated at unit mass resolution in the electron ionization mode using multiple-ion detection, acquiring two characteristic ions for each target analyte and surrogate standard. Analyses of ten percent of samples ( 8 analyses) were confirmed on a high-resolution mass spectrometer.

Initial calibration, to generate relative response factors (RRFs) of native PCB congeners with respect to carbon-13 labeled PCB surrogate standards, was performed using a series of solutions that encompassed the working concentration range of the instrument. The multi-level initial calibration solutions contained the same suite of labeled surrogates as spiked in the samples, recovery standards, and the PCBs targeted for analysis. Calibration was verified at least once every 12 hours by analysis of a mid-level calibration solution.
PCB-congener concentrations were determined with respect to labeled surrogates by the internal standard quantitation method and all reported concentrations are recovery corrected. The recovery of labeled surrogates, added to the sample prior to clean up, was determined against the recovery standard (carbon-13 PCB 138) added to the final extract prior to GC/MS analysis. The laboratory reported 99 peaks (domains) that included 128 target PCB congeners. Isomeric congeners that co-elute on the capillary column were reported as 2- or 3-congener combinations (Appendix A). The sums of the 128-congener concentrations were computed and reported as $\Sigma \mathrm{PCB}$ values.

Aroclor concentrations were estimatcd from the summed peak areas of a suite of "marker peaks" that are congeners characteristic of the particular Aroclor formulation (table 2). The summed peak areas of each marker peak set were converted to concentrations using RRFs derived from a calibration solution that contained equal concentrations of Aroclors 1242, 1254, and 1260. This method uses these sets of marker peaks to express the undegraded Aroclor patterns. The method is especially useful in procedures that allow the congener data to be compared with historical Aroclor data. The congener analytical procedure used in this investigation, however, quantifies most of the congeners that are present in the major Aroclors: 96, 90, 87, and 94 percent of Aroclors 1016, 1242, 1254, and 1260, respectively (Aroclor composition data from Schulz and others, 1989), so the $\Sigma$ PCB values reported here would be within 4 to 13 percent of the total amount of PCBs present in the sample.

Table 2. Analyte ions monitored, surrogates used, and RRF determination for polychlorinated biphenyl Aroclors by HRGC/LRMS

[HRGC/LRMS, high resolution gas chromatography/low resolution mass spectrometry; RRF, relative response factor]

\begin{tabular}{llllr}
\hline \multicolumn{1}{c}{ Aroclor } & Characteristic congeners & Surrogate & $\begin{array}{c}\text { RRF determined } \\
\text { from }\end{array}$ & Recovery standards \\
\hline $1242 / 1016 / 1248$ & $16 / 32,18,17,28,31$ & $13 C-P C B-101$ & 1242 & $13 C-P C B ~ 153$ \\
1254 & $99,97,87$ & $13 C-P C B-101$ & 1254 & $13 C-P C B ~ 153$ \\
1260 & $183,180,170$ & $13 C-P C B-180$ & 1260 & $13 C-P C B$ 153 \\
\hline
\end{tabular}




\section{Statistics for Evaluating Changes in Congener Patterns}

Differences in congener patterns between pairs of samples were quantified by comparing root mean square difference (RMSD) between normalized congener concentrations in the two samples. RMSD was determined as the square root of the sum of squared differences between normalized congener concentrations in the two samples divided by the number of congener pairs compared. Congener pairs were eliminated from compared sample data if the concentration of a congener was below the analytical detection limit in either sample. Congener concentrations were normalized by dividing by summed congener concentration for the sample. Sums of congeners used in normalization for the RMSD computation were based on congener pairs remaining after elimination of below-detection pairs.

RMSD comparison statistics were computed for duplicate samples hung from one buoy, to determine congener variation at a station, and for samples from different stations, to determine variation between stations. These statistics can be used to determine whether the change in pattern between stations is significantly different $(\alpha=0.05)$ from the change in pattern between duplicates by using a t-test (two-sample, assuming equal variances) to compare the mean of the RMSD statistics generated between sites with the mean of the RMSD statistics computed from duplicate comparisons. The means for the t-test were from pooled RMSD comparisons of samples at a station (sample 1 at a station compared to sample 2 at the same station) and from two RMSD comparisons between stations with duplicate sampling (sample 1 at one station compared to sample 1 of a second station and sample 2 of the first station compared to sample 2 of the second station).

\section{POLYCHLORINATED BIPHENYL DATA}

\section{Data Quality}

Field quality-assurance procedures included two equipment blanks submitted blind to the laboratory, deployment of duplicate samplers at each station, and four resamplings at station $\mathrm{M}-29.1-$ one sampling during each of the four deployments. Laboratory quality-assurance procedures included batch analytical runs with procedural blanks; opening, mid-run, and closing calibration checks; and confirmation of analysis of 10 percent of samples by high-resolution mass spectrometry.

The equipment blanks were prepared by filling a sampler with $0.200 \mathrm{~L}$ of hexane in the field, which was poured into an I-Chem jar. None of the 128 congeners reported by the laboratory were detected in either equipment blank (method detection limits ranged from .2 to $0.5 \mathrm{ng}$ per sample).

During the project, 23 pairs of duplicate samples were obtained. The average difference between duplicate-pair $\Sigma$ PCB concentrations ( 27 percent) indicates that the sampling rate of adjacent samplers was not exactly equal. Differences in sampling rate likely were caused by slightly different orientations of the samplers with respect to flow, resulting in different transport rates of water-column PCBs to the sampler membrane surface. Congener concentrations in procedural blanks from the laboratory were all less than detection. Other quality control parameters remained within control limits for all analyses.

Even with a difference in overall sampling rate, the relative sampling rate among congeners would be expected to be the same for both samplers, so that the normalized congener patterns from duplicate samplers would be similar. In fact, the comparison statistic, RMSD, was very low, 0.1 to 0.3 percent, for duplicate sample pairs with $\Sigma$ PCB amounts greater than $100 \mathrm{ng}$. RMSD values for hexane samples with $\Sigma$ PCB amounts less than $100 \mathrm{ng}$ were larger (fig. 2). The relation of RMSD with $\Sigma$ PCB concentration for duplicate pairs is inversely correlated, because the relative precision of analysis decreases as concentrations approach the detection limit of the method. Slight differences in the bar-graph patterns of duplicates can be observed in plots of the duplicate samples (fig. 3). In these plots, as in all the congener plots and tables, congeners are in order of their retention time on the gas chromatograph. This order may correlate with the order of geochemical weathering because the lighter molecular weight, more volatile compounds are the first to emerge from the gas chromatograph followed by progressively heavier molecular weight, less volatile compounds. The plots indicate how the RMSD statistic can pick out differences in duplicates that appear quite similar. 


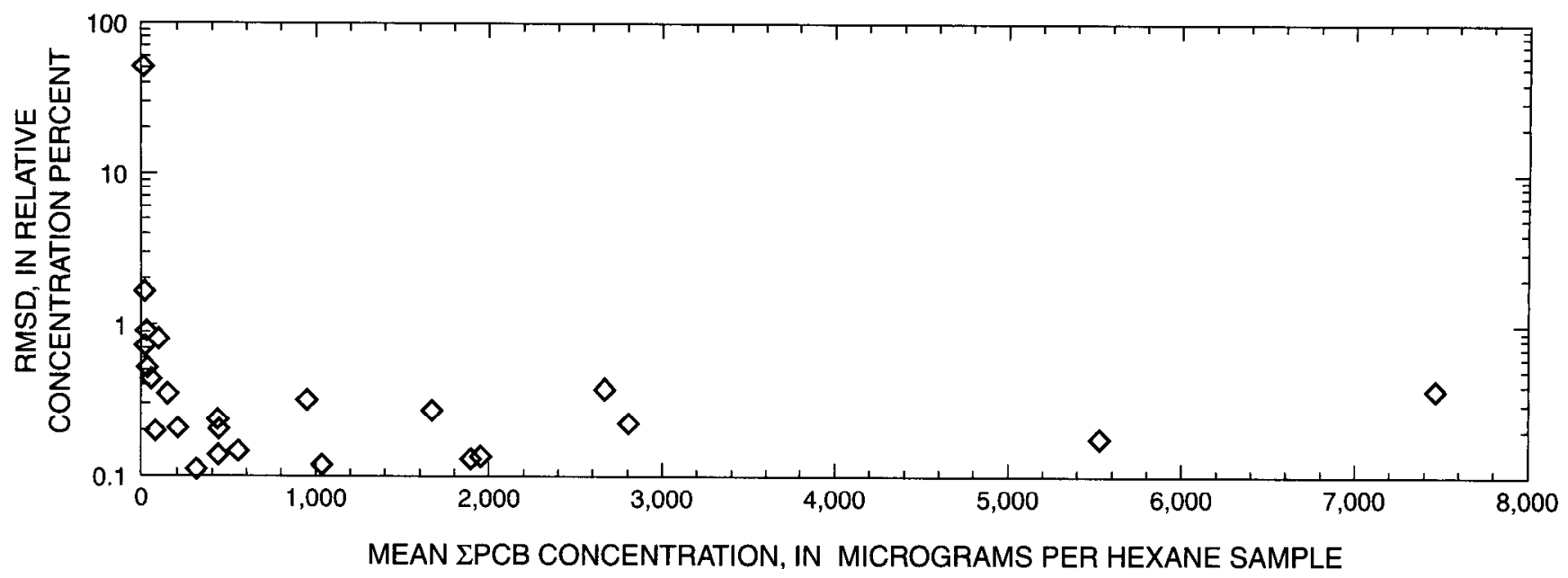

Figure 2. Correspondence of RMSD with mean $\Sigma P C B$ concentration for duplicate samples from the Millers River Basin.

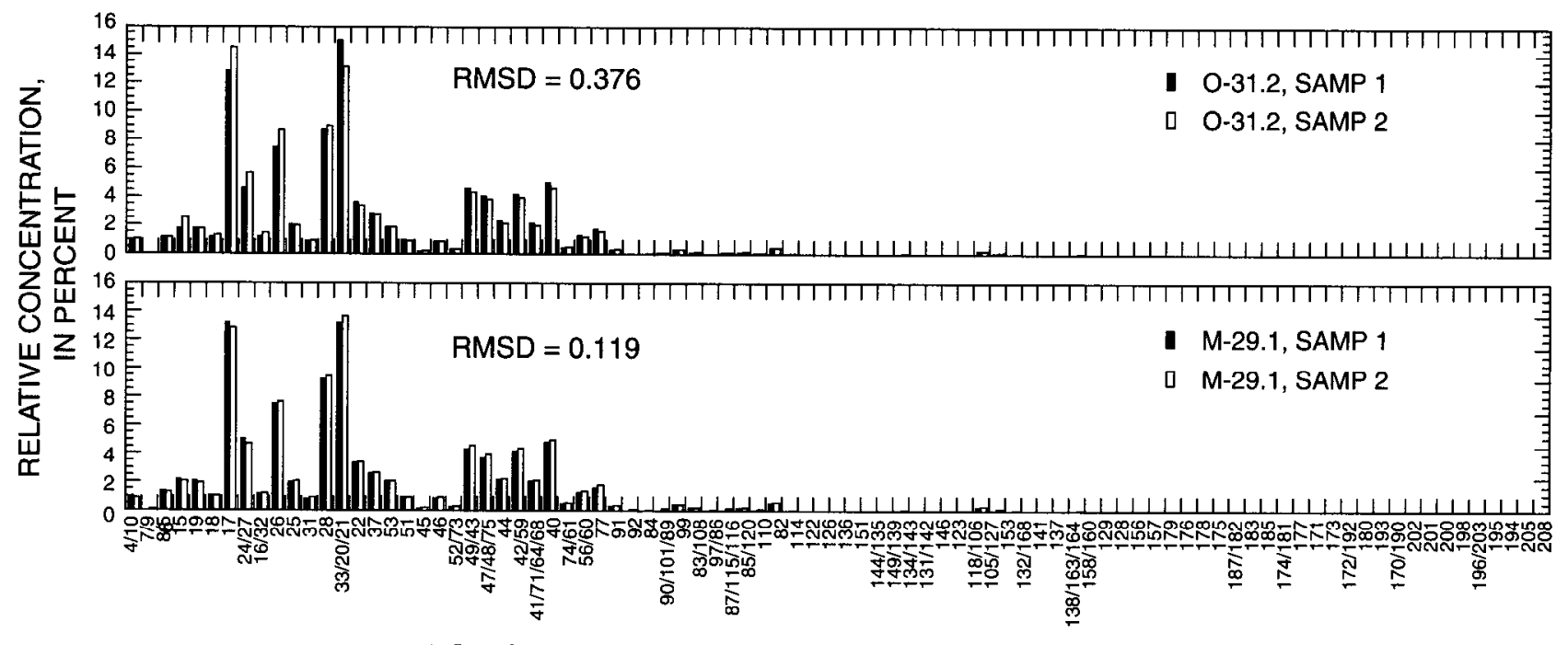

POLYCHLORINATED BIPHENYL CONGENER IUPAC NUMBER

Figure 3. Differences in congener patterns in duplicate samples. [Two bars are plotted at each congener position for two sample pairs with different RMSD values.]

Results of the four repeated samplings at station M-29.1 were consistent (Appendix B). Average deviation of $\Sigma$ PCB from the mean was 24 percent in the first 6 samples ( 3 deployments) collected at the station. The $\Sigma$ PCB concentration of the last sample collected at M-29.1, in November, was only one tenth the average of the previous values.

Low concentrations of PCBs in hexane were obtained in all the November samples (Appendix B), and the November data were not used to interpret PCB source. Possible causes of the low response were lowtemperature water, which would reduce the efficiency of sampling by a factor of 3 (see "Exposure of Fish to Polychlorinated Biphenyls in the Millers River Basin" section), and low concentrations of PCBs in the water column because of dilution from higher flows that occurred in November as compared to the summer period (fig. 4). 


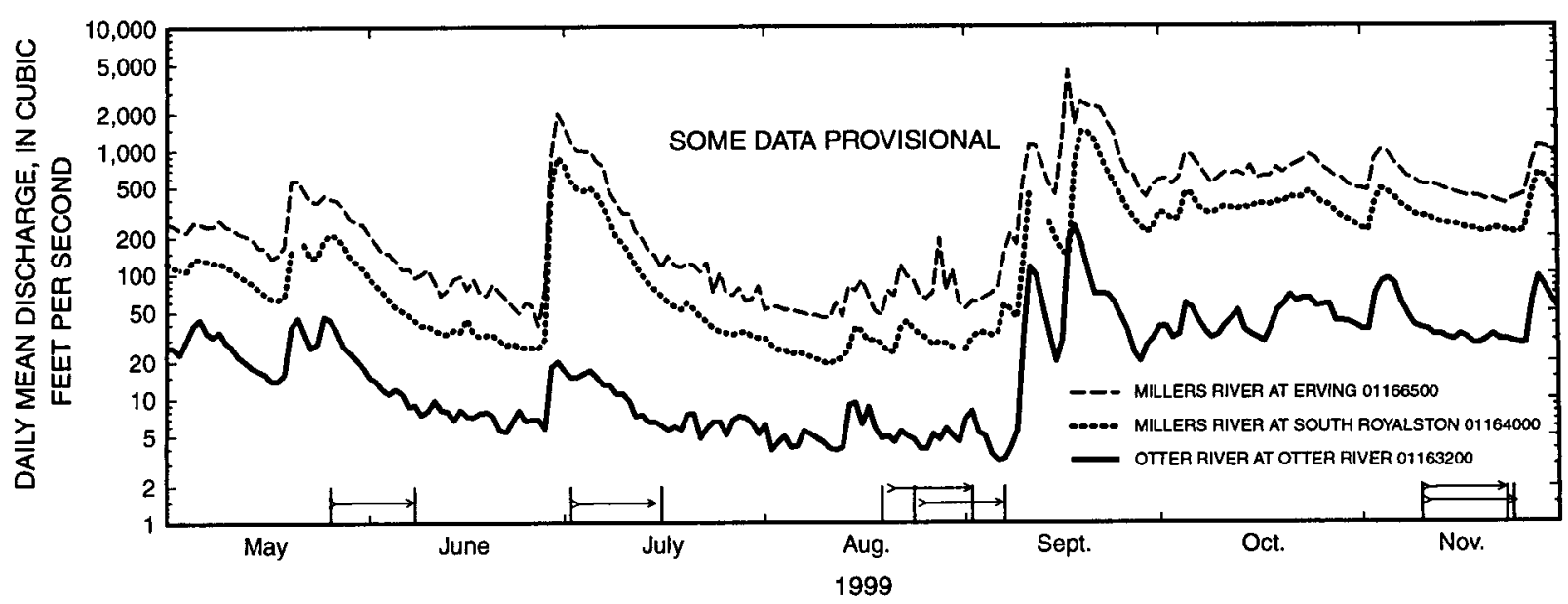

Figure 4. Daily mean discharge data for USGS stream gaging stations at Otter River at Otter River (station number 01163200 ), Millers River at South Royalston (station number 0116400), and Millers River at Erving (station number 01166500). [Data are provisional except for records May through September 1999 for Otter River at Otter River and Millers River at Erving, which are final. Arrows along the date axis indicate the 13- or 14-day periods of PISCES sampler deployment.]

In some cases, the ratio of monitored ion molecular fragments recorded by the mass spectrometer did not pass the laboratory ratio criteria (20 percent of the theoretical) that was established for a congener expected at a particular retention time. Responses with ratios outside the criteria are indicated in the data reported in Appendix B. Generally, peaks that failed the ratio test were minor and did not comprise a substantial fraction of $\Sigma$ PCBs. Occasional large responses that did not meet the criterion-at station M-33.8, sample 2 (congeners 105/127), and station O-34.93, sample 1 (congeners 7/9)-and 2 large responses that did not fit PCB patterns observed in other samplesstation 0-35.20, both samples (congeners 7/9) - were not included in $\Sigma$ PCB or in RMSD calculations.

Samples selected for analysis confirmation by high-resolution mass spectrometry were the low response samples_-background samples and samples collected during November-and one highconcentration sample on the Otter River. The high resolution results (Appendix B) indicated more congener peaks could be identified in the low response samples with high resolution, compared to low resolution, mass spectrometry, and that qualitative and quantitative results were similar for the two methods in the high-concentration sample.

\section{Sampling Results}

The deployment of samplers was successful at most stations; however, on six occasions one sampler of a duplicate deployment was lost (table 1). Recoveries of the initial $0.200 \mathrm{~L}$ hexane from successful deployments averaged $0.173 \mathrm{~L}$ ( 66 samplers with a standard deviation of $0.017 \mathrm{~L}$ ). Streamflow during deployment of samplers was constant or decreasing (fig. 4), so that samplers suspended in the water column (not resting on the streambed) at retrieval could be assumed to have remained suspended throughout the entire period of deployment. On three occasions, samplers had settled to the streambed by the end of deployment, once because of a punctured buoy. Depending on duration of sampler grounding (which is unknown), results from grounded samplers may not have represented water-column conditions accurately and were flagged where reported in figures and tables.

A large range of $\Sigma$ PCB concentrations was measured through deployment of the passive samplers-from 1 to $8,000 \mathrm{ng} /$ hexane sample (table 3). Units of PCB weight/hexane sample were used to avoid mistaking passive-sample results for concentrations in ambient water. The highest concentrations measured were more than 10 times greater than those reported in a previous PCB point-source investigation in the Black River, New York, in which passive samplers were used (Litten and others, 1993). 
Table 3. Sums of congeners, Aroclor mixtures from passive samplers, and computed water-column concentrations at stations on the Millers River and the Otter River, Massachusetts

[Water temperatures used to compute water-column concentrations were averages of mean daily temperatures for the deployment period at the U.S. Geological Survey continuous-record gage on the Stillwater River near Sterling, Mass., 01095220: May deployment, $19.3^{\circ} \mathrm{C}$; July deployment, $21.3^{\circ} \mathrm{C}$; August deployment, $19.3^{\circ} \mathrm{C}$; November deployment, $5.8^{\circ} \mathrm{C}$; ND, below detection limit; No., number; $\Sigma$ PCB, summed concentrations of all targeted polychlorinated biphenyl congeners; ng/hexane sample, nanograms per hexane sample; ng/L, nanograms per liter]

\begin{tabular}{|c|c|c|c|c|c|c|c|}
\hline Station No. & $\begin{array}{c}\text { Date } \\
\text { deployed }\end{array}$ & Sample No. & $\begin{array}{c}\sum P C B \\
\text { (ng/hexane } \\
\text { sample) }\end{array}$ & $\begin{array}{c}\text { Aroclor } \\
1016 \text { and } 1242 \\
\text { (ng/hexane } \\
\text { sample) }\end{array}$ & $\begin{array}{c}\text { Aroclor } 1254 \\
\text { (ng/hexane } \\
\text { sample) }\end{array}$ & $\begin{array}{c}\text { Aroclor } 1260 \\
\text { (ng/hexane } \\
\text { sample) }\end{array}$ & $\begin{array}{c}\text { Water-column } \\
\text { concentration } \\
\text { (ng/L) }\end{array}$ \\
\hline $0-41.8$ & $5-26-99$ & 1 & 18 & 17 & ND & 7 & 0.8 \\
\hline $0-41.8$ & $5-26-99$ & 2 & 17 & 18 & ND & 8 & .8 \\
\hline O-39.9 & $5-26-99$ & 1 & 19 & 17 & ND & 8 & .9 \\
\hline $0-36.9$ & $5-26-99$ & 1 & 9 & 9 & ND & 5 & .4 \\
\hline $0-36.9$ & $5-26-99$ & 2 & 11 & ND & ND & ND & .5 \\
\hline $0-36.2$ & $5-26-99$ & 1 & 10 & 7 & ND & 4 & .5 \\
\hline $0-36.2$ & $5-26-99$ & 2 & 12 & 8 & ND & 7 & .7 \\
\hline $0-35.4$ & $11-10-99$ & 1 & ND & ND & ND & ND & ND \\
\hline $0-35.20$ & $8-24-99$ & 1 & 29 & 33 & 11 & ND & 1.5 \\
\hline $0-35.20$ & $8-24-99$ & 2 & 15 & 21 & 11 & 2.6 & 1.1 \\
\hline $0-35.17$ & $11-10-99$ & 1 & $\mathrm{ND}$ & ND & ND & ND & ND \\
\hline O-34.99 & 8-24-99 & 1 & 55 & 61 & 21 & ND & 2.2 \\
\hline $0-34.99$ & $8-24-99$ & 2 & 37 & 47 & 13 & ND & 1.5 \\
\hline O-34.97 & $8-24-99$ & 1 & 120 & 100 & 52 & 11 & 4.7 \\
\hline $0-34.97$ & $8-24-99$ & 2 & 56 & 61 & 20 & ND & 2.2 \\
\hline $0-34.97$ & $11-10-99$ & 1 & ND & ND & ND & ND & ND \\
\hline $0-34.93$ & $8-24-99$ & 1 & 78 & 77 & 27 & 5.2 & 3.6 \\
\hline O-34.93 & $8-24-99$ & 2 & 67 & 65 & 22 & 4.6 & 2.6 \\
\hline $0-34.7$ & $8-24-99$ & 1 & 130 & 160 & 27 & ND & 5.0 \\
\hline $0-34.7$ & $8-24-99$ & 2 & 160 & 220 & 28 & ND & 6.3 \\
\hline $0-34.5$ & $8-24-99$ & 1 & 190 & 260 & 31 & 3.8 & 7.7 \\
\hline O-34.5 & 8-24-99 & 2 & 210 & 290 & 32 & 3.2 & 8.3 \\
\hline O-33.7 & $5-25-99$ & 1 & 1,200 & 1,800 & 99 & 9 & 43 \\
\hline O-33.7 & $5-25-99$ & 2 & 750 & 1,100 & 79 & 9 & 28 \\
\hline O-33.1 & $8-19-99$ & 1 & 1,860 & 3,200 & 130 & 3.6 & 77 \\
\hline $0-33.1$ & $8-19-99$ & 2 & 2,380 & 5,500 & 310 & 11 & 140 \\
\hline $0-32.1$ & $8-19-99$ & 1 & 2,200 & 3,700 & 140 & 2.7 & 94 \\
\hline $0-32.1$ & $8-19-99$ & 2 & 3,310 & 5,600 & 210 & 5.3 & 140 \\
\hline 0.31 .2 & $5-25-99$ & 1 & 8,000 & 12,000 & 640 & ND & 300 \\
\hline $0-31.2$ & $8-19-99$ & 1 & 7,310 & 12,000 & 430 & 7.2 & 300 \\
\hline $0-31.2$ & $8-19-99$ & 2 & 7,370 & 13,000 & 400 & 7.0 & 310 \\
\hline M-33.8 & $5-25-99$ & 1 & 4 & ND & ND & ND & .1 \\
\hline$M-33.8$ & $5-25-99$ & 2 & 1 & ND & ND & ND & .08 \\
\hline M-31.2 & $5-25-99$ & 1 & 9 & 9 & 8 & ND & .4 \\
\hline M-29.1 & $5-25-99$ & 1 & 1,900 & 2,800 & 160 & ND & 70 \\
\hline$M-29.1$ & $5-25-99$ & 2 & 1,500 & 2,100 & 170 & 6 & 55 \\
\hline M-29.1 & $7-02-99$ & 1 & 2,200 & 3,600 & 200 & ND & 72 \\
\hline M-29.1 & $7-02-99$ & 2 & 1,700 & 2,600 & 160 & ND & 54 \\
\hline
\end{tabular}


Table 3. Sums of congeners, Aroclor mixtures from passive samplers, and computed water-column concentrations at stations on the Millers River and the Otter River, Massachusetts-Continued

\begin{tabular}{lrrrrcrc}
\hline Station No. & $\begin{array}{c}\text { Date } \\
\text { deployed }\end{array}$ & Sample No. & $\begin{array}{c}\text { SPCB } \\
\text { (ng/hexane } \\
\text { sample) }\end{array}$ & $\begin{array}{c}\text { Aroclor } \\
\text { 1016 and 1242 } \\
\text { (ng/hexane } \\
\text { sample) }\end{array}$ & $\begin{array}{c}\text { Aroclor 1254 } \\
\text { (ng/hexane } \\
\text { sample) }\end{array}$ & $\begin{array}{c}\text { Aroclor 1260 } \\
\text { (ng/hexane } \\
\text { sample) }\end{array}$ & $\begin{array}{c}\text { Water-column } \\
\text { concentration } \\
\text { (ng/L) }\end{array}$ \\
\hline M-29.1 & $8-19-99$ & 1 & 900 & 1,500 & 77 & 2.3 & 37 \\
M-29.1 & $8-19-99$ & 2 & 1,150 & 1,900 & 89 & ND & 48 \\
M-29.1 & $11-10-99$ & 1 & 180 & 260 & ND & ND & 20 \\
M-27.5 & $7-02-99$ & 1 & 1,700 & 2,600 & 200 & ND & 56 \\
M-27.5 & $7-02-99$ & 2 & 2,000 & 3,100 & 220 & ND & 65 \\
M-21.0 & $7-02-99$ & 1 & 390 & 530 & 59 & ND & 13 \\
M-18.1 & $7-02-99$ & 1 & 450 & 570 & 78 & ND & 15 \\
M-18.1 & $7-02-99$ & 2 & 410 & 500 & 80 & ND & 13 \\
M-14.7 & $7-02-99$ & 1 & 620 & 800 & 110 & ND & 20 \\
M-12.8 & $7-02-99$ & 1 & 350 & 450 & 71 & ND & 12 \\
M-12.8 & $7-02-99$ & 2 & 270 & 340 & 51 & ND & 8.7 \\
M-12.8 & $11-10-99$ & 1 & 45 & 66 & ND & ND & 5.1 \\
M-10.9 & $11-10-99$ & 1 & 58 & 80 & ND & ND & 6.4 \\
M-10.4 & $11-10-99$ & 1 & 110 & 160 & ND & ND & 14 \\
M-10.3 & $11-10-99$ & 1 & 130 & 160 & ND & ND & 12 \\
M-9.8 & $7-02-99$ & 1 & 370 & 440 & 78 & ND & 15 \\
M-9.8 & $7-02-99$ & 2 & 490 & 590 & 95 & ND & 20 \\
M-8.0 & $7-02-99$ & 1 & 550 & 640 & 120 & ND & 23 \\
M-8.0 & $7-02-99$ & 2 & 540 & 650 & 100 & ND & 22 \\
M-2.6 & $7-02-99$ & 1 & 410 & 470 & 92 & ND & 17 \\
M-2.6 & $7-02-99$ & 2 & 460 & 540 & 100 & ND & 19 \\
M-0.1 & $7-02-99$ & 1 & 260 & 280 & 70 & ND & 10 \\
\hline & & & & & & & \\
\hline
\end{tabular}

The PCB concentrations in terms of Aroclors (table 3) indicated Aroclor 1016/1242 dominated the highconcentration samples, although small concentrations of 1254 and 1260 were also reported. $\Sigma$ PCB concentration often was less than the total concentration of the estimated Aroclors. These discrepancies may have been caused by unquantified congeners (as discussed in the Analytical Laboratory Procedures section), by altered environmental congener patterns caused by geochemical weathering, or analytical error in either the congener or the Aroclor determination. Generally, PCB concentrations estimated by Aroclor are biased high because of overlapping patterns of the Aroclor mixtures (Eganhouse, 1991).

All sample congener concentration results are plotted as bar graphs in the Appendix B. Visual comparison of the congener patterns in the bar graphs indicates many of the samples have similar congener patterns, as confirmed by statistical comparisons described in the following section.

\section{IDENTIFICATION OF SOURCES OF POLYCHLORINATED BIPHENYLS}

Sources of PCBs can be inferred between stations where there is a change in PCB concentration, in PCB-congener patterns, or in both concentration and pattern (Litten and others, 1993). These changes can be observed in a plot of average $\Sigma$ PCB concentration at a station and of RMSD between adjacent stations displayed in downstream order (fig. 5). 


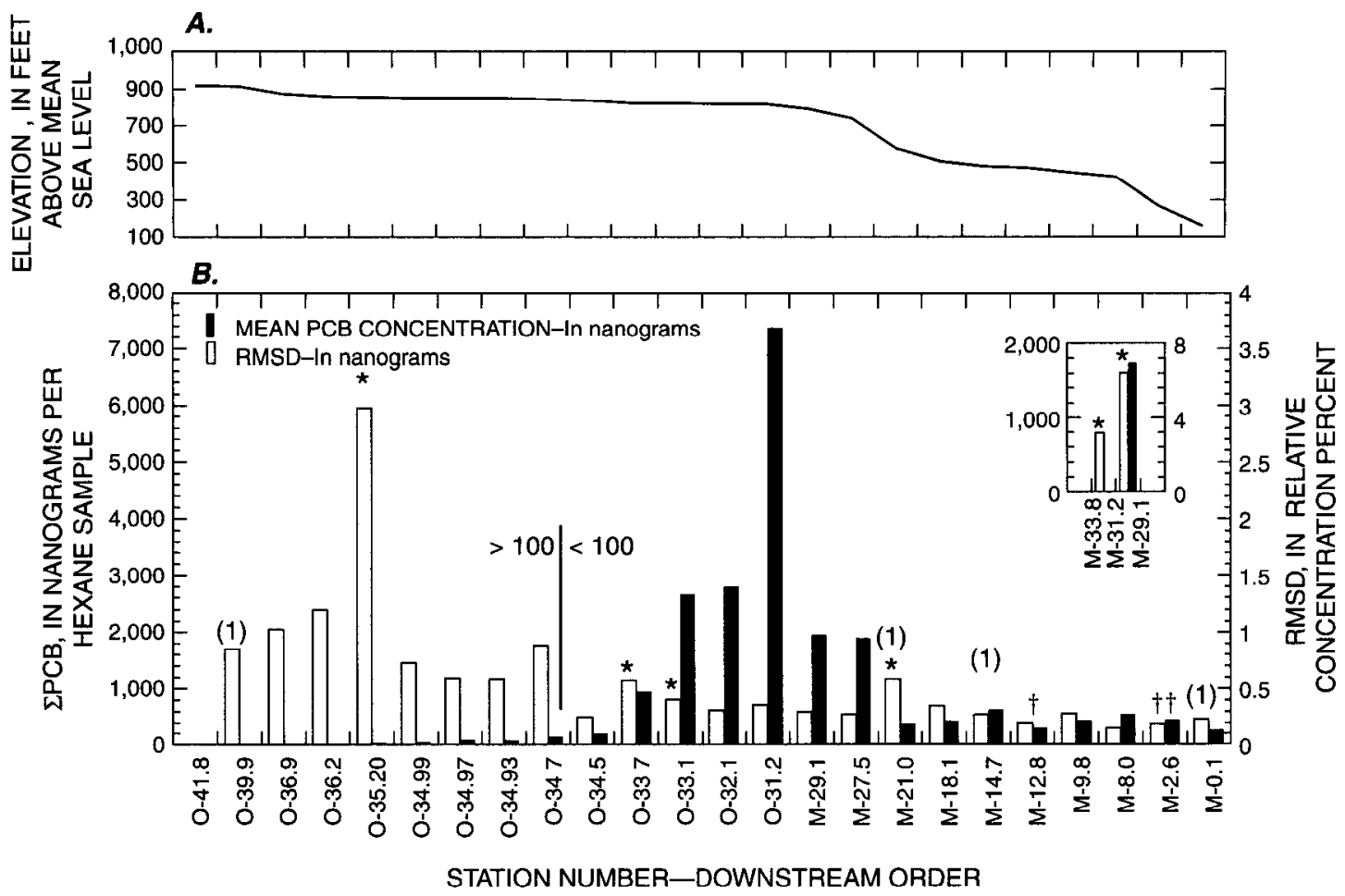

Figure 5. $(A)$ Streambed elevation profile of the Millers River from the Connecticut River to the confluence with the Otter River and of the Otter River to its source (Massachusetts Division of Water Pollution Control, 1980) and (B) $\Sigma$ PCB and between-station RMSD of congener concentrations in downstream order on the Otter River and the Millers River. [Data from stations sampled only in November are not displayed because of low response obtained during that sampling. Concentrations are means of two samples and RMSD are means of two sample comparisons unless indicated by (1) above the bars, where a sample was lost; * means t-test comparison showed between-station RMSD was significantly greater than within station RMSD; † means samplers were grounded on mud; 怗 means samplers were grounded on cobbles.]

\section{Sources Upstream from Birch Hill Dam}

On the Otter River, $\Sigma \mathrm{PCB}$ concentrations increased many fold in the downstream direction, beginning at station $\mathrm{O}-35.20$, with a maximum concentration increase occurring between stations O-32.1 and O-31.2 (fig. 5). Maximum pattern change, as indicated by RMSD, was computed farther upstream, between stations O-36.2 and O-35.20. Actually, a large $\Sigma \mathrm{PCB}$ concentration change in percentage terms was measured coincident with the pattern change between stations O-36.2 and O-35.20 (table 3), but the absolute concentrations involved were small. The progressive increase of $\Sigma \mathrm{PCB}$ concentrations downstream from the maximum change in pattern is compatible with a hypothesized PCB source that is distributed over a downstream reach between stations $\mathrm{O}-36.2$ and $\mathrm{O}-31.2$.
Bar charts of the congener patterns from stations on the Otter River (fig. 6) show the nature of the pattern change coincident with the maximum RMSD between O-36.2 and O-35.20. Generally the lower weight congeners (congeners containing fewer chlorine atoms) increase from $\mathrm{O}-36.2$ to $\mathrm{O}-35.2$ relative to the higherweight congeners (congeners containing more chlorine atoms). Of five groups of congeners that increase (marked by brackets below the axis for sample O-35.20 in figure 6), only one (group 4) is present in O-36.2 with essentially the same pattern (although $42 / 59$ is missing) as in station O-35.20. Downstream from $\mathrm{O}-35.20$, the pattern in the five groups does not change from sample to sample, and the concentrations of the lower-weight congeners continue to increase relative to higher-weight congeners. 

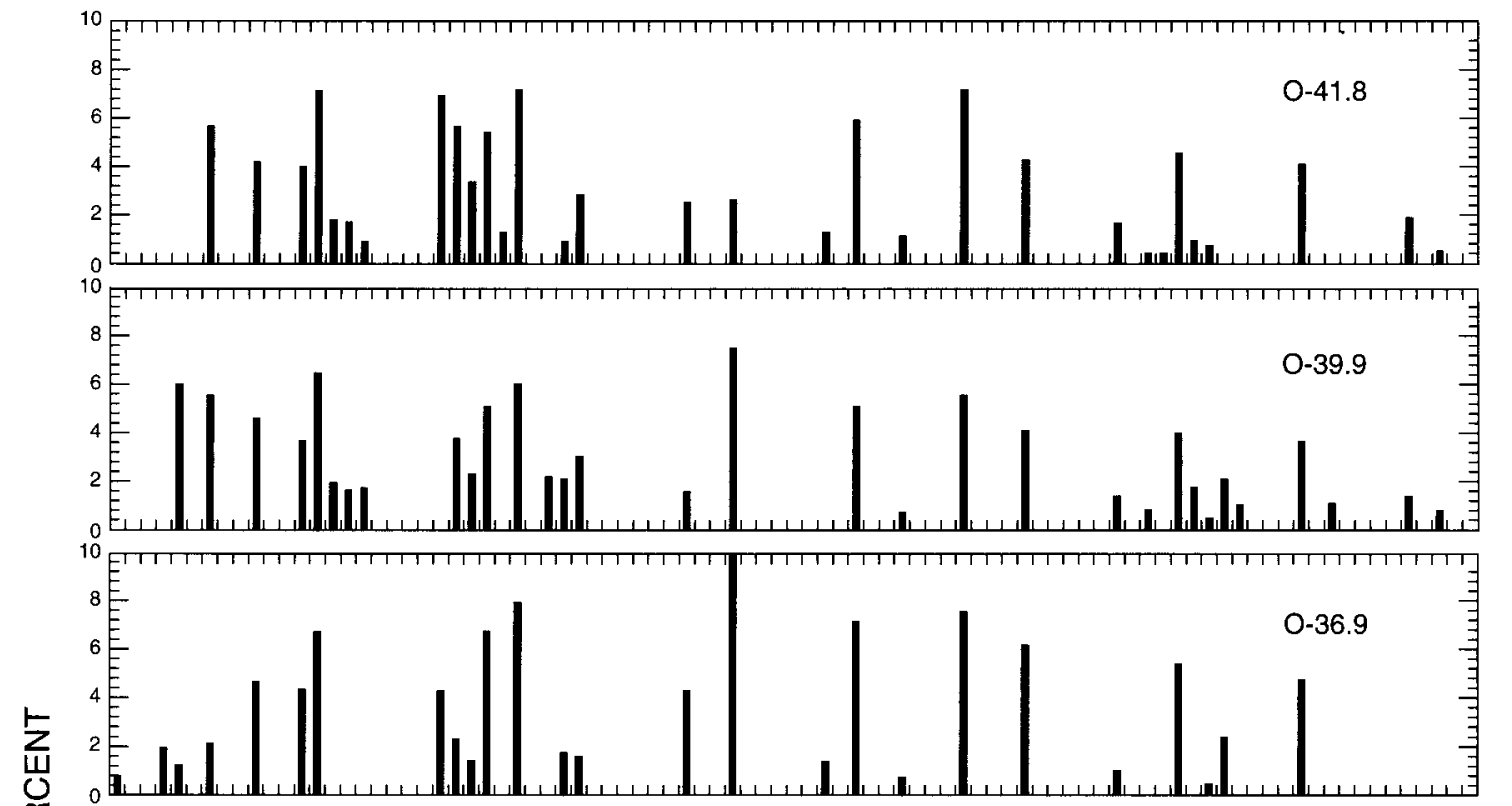

$$
\text { ż }
$$

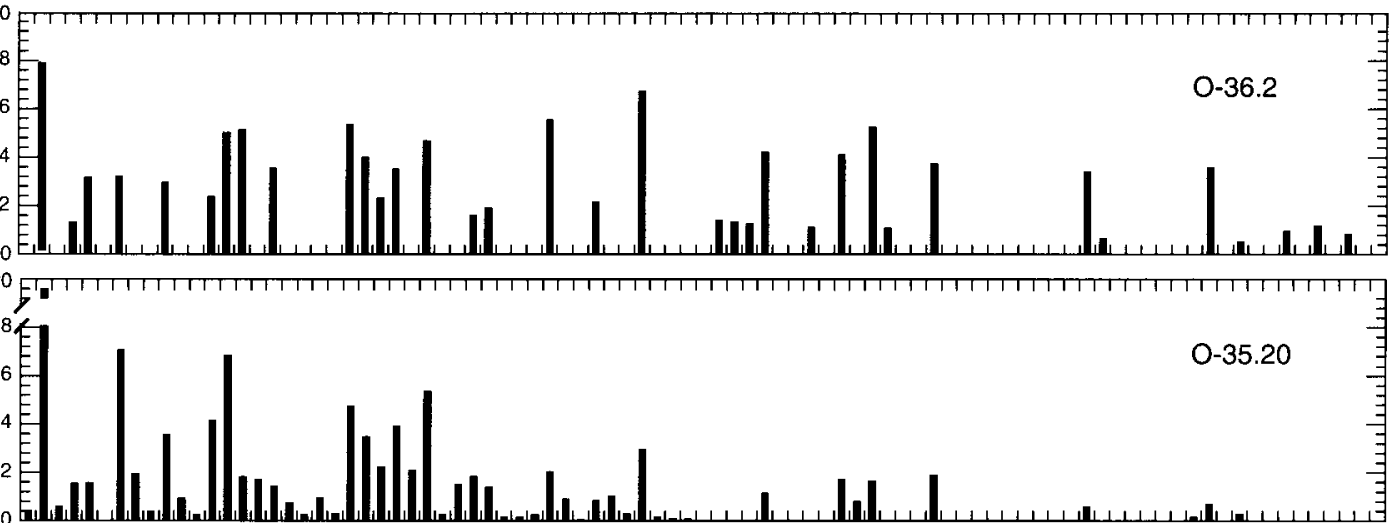

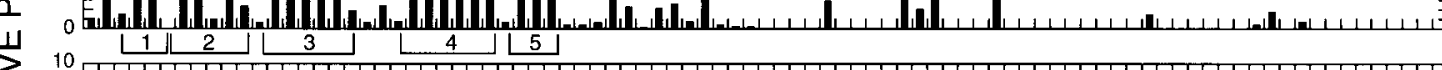
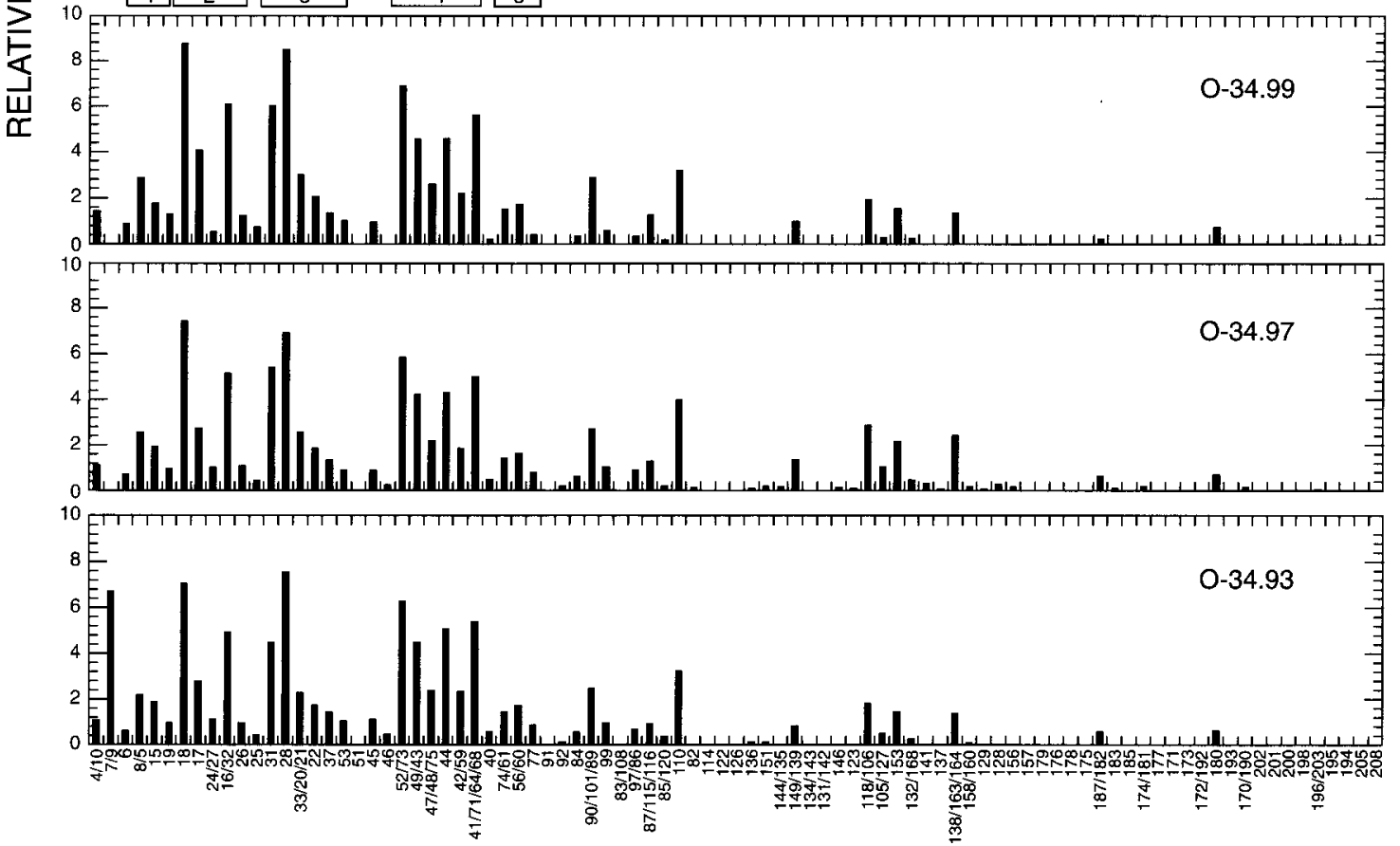

POLYCHLORINATED BIPHENYL CONGENER IUPAC NUMBER

Figure 6. PCB congener patterns in the Otter River. [Mean relative congener concentration values from two samples recovered at each site are displayed except for station 0-39.9, where only one sample was recovered. When more than one congener is displayed for one bar, multiple IUPAC numbers are separated by a slash.] 
¿PCB concentrations measured on the upper Millers River just upstream from the confluence with the Otter River, stations M-31.2 and M-33.8, were low (averages of 3 and $9 \mathrm{ng} /$ hexane sample, which are too small to show in the inset, fig. 5) but increased to a high concentration (average $1,700 \mathrm{ng} /$ hexane sample) downstream from the confluence with the Otter River at station M-29.1. Congener pattern change, as evaluated by RMSD, was high between stations M-33.8 and M-31.2 and higher still between stations M-31.2 and M-29.1. These results reflect (1) the high relative error associated with congener analysis at low concentration, and (2) $\Sigma$ PCB concentration in the upper Millers River that was much lower upstream from the confluence with the Otter River than downstream and much different in congener pattern. The low $\Sigma$ PCB concentrations at stations M-31.2 and M-33.8, indicate that there was not a PCB point source on the upper Millers River.

\section{Conceptual Model of Source}

Conceptually, a source distributed between stations O-36.2 and O-31.2 for the dissolved PCBs measured in the water column could be PCB-contaminated, fine-grained sediment on the stream bed. As noted in past investigations, high concentrations of PCBs (to $250 \mu \mathrm{g} / \mathrm{g}$ ) have been measured in streambed sediments from the Millers River upstream from the Birch Hill Dam and from the lower Otter River (U.S. Army Corps of Engineers, 1995). Because PCBs have not been manufactured commercially in the United States since 1977, active PCB discharge, such as that from industrial processing, has slowed or stopped in most locations. Current detections of PCBs in the dissolved phase are often from reservoirs of historical PCB discharge such as in ground water (for example, in the Housatonic River, Mass., S. Svirsky, U.S. Environmental Protection Agency, oral commun., 2000), landfills, or on stream sediments (for example, in the Fox River, Wis., William and others, 1997). Release from bed sediment distributed along a river reach would account for the progressive total PCB concentration increase and the congener-pattern change in the downstream direction measured in the Otter River-the greater the volume of contaminated sediment passed over by stream water, the greater the amount of PCBs picked up by the water.
Exchange of PCBs between the water column and the sediments is commonly modeled as an equilibrium process with net transport direction depending on relative concentrations of $\mathrm{PCBs}$ adsorbed onto the sediments and dissolved in the water column (Mackay and others, 1992). During active discharge of PCBs into the water column, net transport would be from water to sediments, resulting in PCB loading of the solid phase. When discharge of PCBs into the stream is decreased or ended, the direction of PCB transport to achieve equilibrium would change to desorption from sediments to the water. Partition coefficients for PCBs between particulate organic carbon and water $\left(\mathrm{K}_{\mathrm{OC}}\right)$ range from $10^{4}$ for PCB-4 to $10^{8}$ for PCB-209 (Mackay and others, 1992). Large $K_{o c}$ values mean that large amounts of PCBs could build up in sediments rich in organic matter during active $\mathrm{PCB}$ discharge. If active PCB discharge ceased or decreased, sorbed PCBs could move back into the water column from reworking of the contaminated sediments over a long period of time.

Commonly, fine-grained sediments in the first depositional zone downstream from a PCB release point are highly contaminated with PCBs that have partitioned to the solid phase (Gay and Frimpter, 1985). The stream gradient in the Otter River decreases downstream from station O-36.2 as the stream enters an extensive zone of fine-grained wetland deposits associated with the Birch Hill Dam. Thus, progressive increase of PCB downstream from O-36.2 may be caused in part by an increasing fraction, in the downstream direction, of streambed sediment that is fine-grained and that contains sorbed PCBs.

If the present water-column source of PCBs is historically contaminated streambed sediments, the point of historical active discharge for PCBs would be upstream from the point at which significant watercolumn PCB concentration increases and congener pattern changes occur. In the Otter River, the concentration increase (doubling) that occurs farthest upstream and the greatest congener pattern change occur between stations O-36.2 and O-35.20. Station O-35.20 is upstream from pipe outfalls in the community of Baldwinville, including the waste-water treatment plant in Baldwinville that collects and treats waste from residences and industries in the community. However, sludge from the treatment plant is landfilled adjacent to the Otter River, upstream from the plant and upstream from station O-35.20. PCBs may have been discharged to the Otter River before the treatment plant went on 
line (1979), existed in treatment plant effluent at some concentration after plant construction, and may have seeped into the river from the landfilled sludge.

\section{Correspondence with Aroclors}

The congener pattern least affected by PCBs from upstream of station 0-35.20 and most strongly reflecting the source material is present in the three highest-concentration samples measured at station O-31.2 (Appendix B). Bar-graphs of congeners averaged from the three samples at O-31.2 compared with bar graphs of light Aroclors (1016 and 1242) (fig. 7), generally match well, although low-molecular weight congeners are slightly more prevalent in the O-31.2 sample. Also, the prominent peak at $8 / 5$ in the Aroclors is more than six times greater than the same peak in the O-31.2 sample. The statistical comparison, RMSD, between the light-weight Aroclors and the O-31.2 sample is in the range of 1.2 to 1.3 percent-about five times greater than RMSD values for comparison of replicates at a station. The congener pattern is not inconsistent with a source of Aroclor 1016 or 1242. The hypothesized processes of sorption and desorption on the sediments before collection by the passive samplers might have altered the congener pattern so that an exact match would not be expected.

\section{Congener Pattern Weathering and Sources Downstream from Birch Hill Dam}

Downstream from the peak $\Sigma$ PCB concentration at station 0-31.2 (average of 7,560 ng/hexane sample), $\Sigma P C B$ concentrations decreased by a factor of four to the closely spaced stations of M-29.1 and M-27.5 and

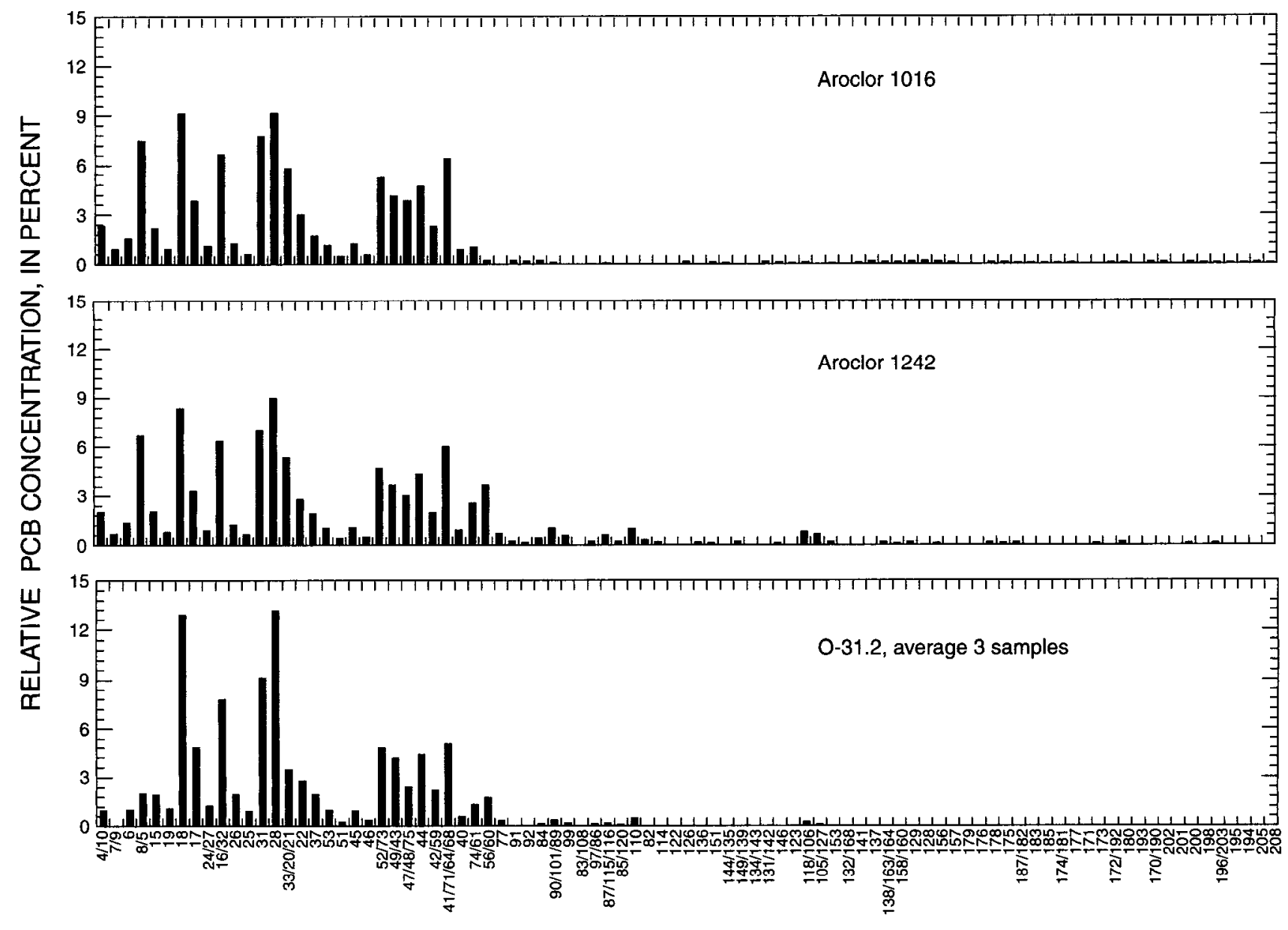

POLYCHLORINATED BIPHENYL CONGENER IUPAC NUMBER

Figure 7. Relative PCB concentration congener patterns compared, average of three samples from station 0-31.2 with patterns of Aroclor 1016 and 1242. 
then decreased again by a factor of four to the more distant station M-21.0 (fig. 5). From station M-21.0 downstream $13 \mathrm{mi}$ to station M-8.0, concentrations were relatively constant, fluctuating between 310 and $625 \mathrm{ng} / \mathrm{hexane}$ sample. Among the last three stations, M-8.0, M-2.6, and M-0.1, $\Sigma$ PCB concentrations decreased from 550 to $260 \mathrm{ng}$ per sample.

The initial decrease, between stations 0-31.2 and M-29.1 likely was caused by streamflow dilution from the upper Millers River, in which $\Sigma$ PCB concentrations were low. The ratio of streamflows during the 2-weeks of sampler deployment at the USGS gaging station 01164000 (M-27.5) on the Millers River to USGS gaging station 01163200 on the Otter River, $6.1 \mathrm{mi}$ upstream from the confluence, was approximately $5: 1$ (fig. 4). The ratio of flows likely would approach the PCB dilution ratio, 4:1, if Otter River flow were measured at the confluence rather than $6.1 \mathrm{mi}$ upstream. The second four-fold decrease, between stations $M$ 27.5 and M-21.0, occurred in a reach where few tributaries enter the Millers River. This reach is high gradient, as noted in the basin description, and may be especially susceptible to PCB loss through volatilization to the atmosphere. The steep gradient also means that sedimentation of fine-grained suspended sediments and associated PCBs is unlikely, so that contaminated sediments would be relatively unavailable for PCB desorption into the water column in this reach.

Changes in congener patterns associated with the PCB decreases between the two sets of stations can confirm possiblc causes of the decreases. T-test comparisons indicated change in pattern between stations was not significantly different $(\alpha=0.05)$ from change in duplicates at a station for the first concentration decrease, between stations O-31.2 and M-29.1. Pattern change was significant, however, at the second decrease, between stations M-27.5 and M-21.0 (fig. 5). Dilution by the upper Millers River water, which was virtually devoid of PCBs, would not cause a pattern change, because all congeners would be reduced by the same amount and their relative abundance would be maintained. Decreased concentrations resulting from volatilization might cause a congener-pattern change because large molecular-weight congeners (those with many chlorine atoms) are volatilized less readily from water than are low molecular-weight congeners (Mackay, 1992).
The nature of the pattern change can be expressed by ratios, $R_{n, x}$, of normalized congener concentrations in successive samples downstream (stations M-29.1 through M-0.1) to an upstream sample, O-31.2, defined,

$$
\begin{aligned}
& \text { \% contribution of congener } n \text { to total } \\
& R_{n, x}=\frac{\text { PCBs in sample } x}{\% \text { contribution of congener } n \text { to total }}
\end{aligned}
$$

$R_{n, x}$ values equal one where there was no change in the relative contribution of that congener to $\Sigma$ PCBs of the sample by comparison with the contribution of the same congener to $\Sigma$ PCBs at O-31.2. Congener ratios are greater than one for congeners that are enriched relative to $0-31.2$ and less than one for congeners that are depleted relative to $0-31.2$. When plotted in order of gas chromatograph retention time, a consistent congener-pattern change, such as from biogeochemical weathering, would be indicated by a progressive enrichment or depletion of congener along the retention-time axis. At the first two stations on the Millers River downstream from O-31.2, $R_{n, x}$ values were relatively constant and close to one (fig. $8 A$ ). Ratios for the next stations downstream, M-21.0 and M-18.1, indicated enrichment of the higher molecular weight congeners and depletion of the lower molecular weight congeners (fig. 8B). The same shift in congener pattern present for the $\mathrm{M}-21.0$ and $\mathrm{M}-18.1$ stations appeared in ratios for the next four stations downstream (fig. $8 C$ and $D$ ). Finally, the shift was greatest at the last two stations before the confluence of the Millers River with the Connecticut River at stations M-2.6 and M-0.1 (fig. 8E).

These results are compatible with the hypothesized cause of decreases in $\Sigma$ PCB in the steep-gradient reaches betwecn stations $M-27.5$ and $M-21.0$ and between M-8.0 and M-0.1. Because of the steep gradient in these reaches, gas transfer increases across the air-water interface (Parker and Gay, 1987) and removal of the lower-molecular weight, more-volatile congeners might occur at a faster rate than for the higher-molecular weight, less-volatile congeners. Lack of pattern change and a lack of continued decrease in $\Sigma$ PCB between M-21.0 and M-8.0 may reflect the flat gradient and low rates of volatilization in addition to replenishment of PCBs in the water column from fine-grained sediments deposited in these reaches. 

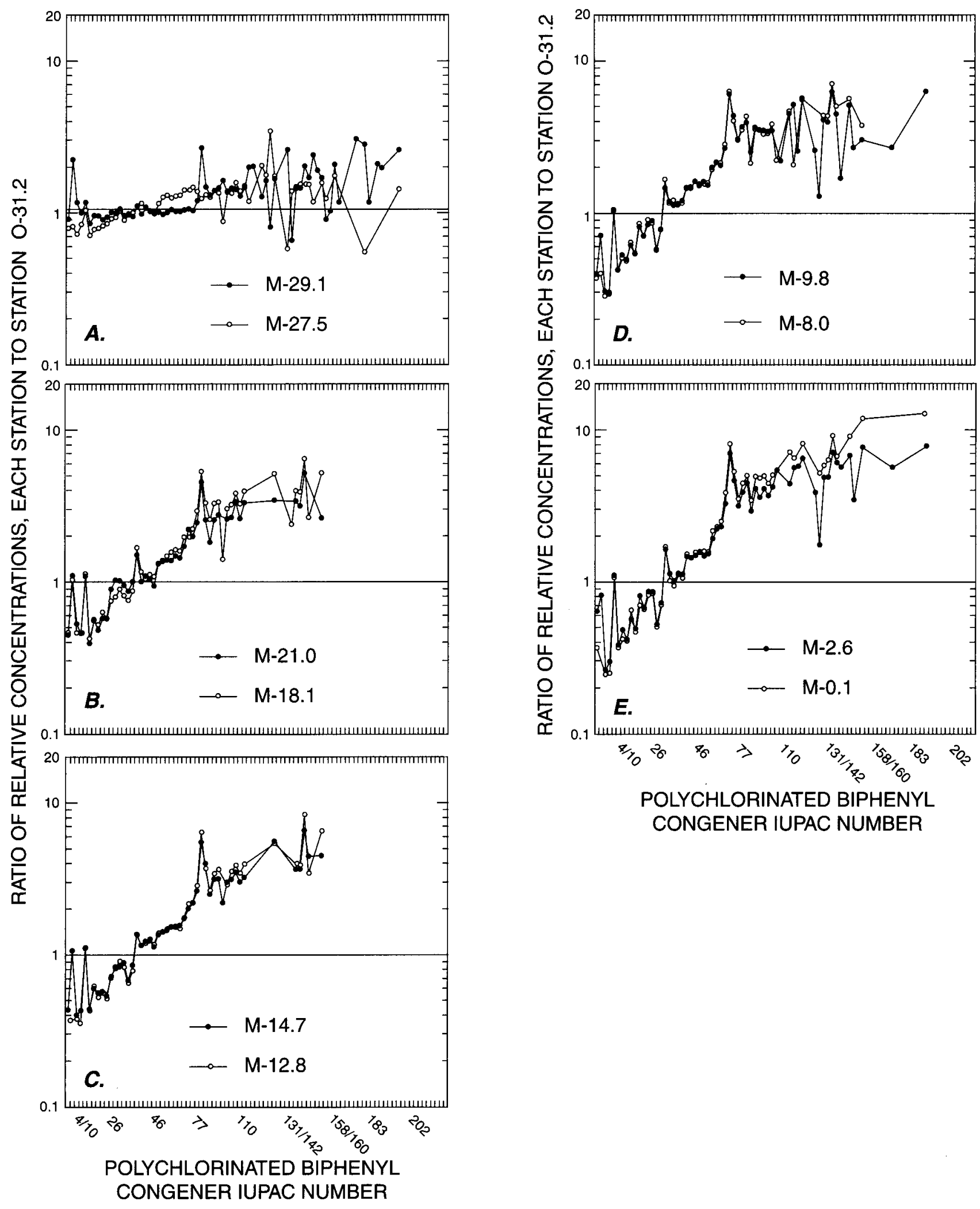

Figure 8. Ratio comparisons of normalized PCB congener concentrations. [Ratios are normalized congeners from each station divided by the normalized congener concentration at station 0-31.2.] 
These effects are consistent with a similar weathering of congener pattern observed among stations in lower Green Bay, Wisc., with distance from the Fox River, a source of Aroclor 1242 (Willman and others, 1997).

Passive-sampler results do not lend support to a hypothesized additional source of PCBs to the Millers River below the Birch Hill Dam. $\mathrm{SPCB}$ concentrations were generally unchanging or decreasing in the downstream direction, and changes of the congener pattern appear to reflect weathering of the pattern from above Birch Hill Dam rather than the addition of new material. Also, the sampler results do not support introduction of new material to the lower river even from exactly the same type of source (and thus congener pattern) as hypothesized to have entered in Baldwinville. Unweathered PCBs from a similar source would "reset" the congener pattern to resemble more closely the concentrations observed at station $\mathrm{O}-31.2$. In contrast, the trend of progressive weathering downstream from $0-31.2$ is not reset; the trend continues to the end of the Millers River.

\section{EXPOSURE OF FISH TO POLYCHLORINATED BIPHENYLS IN THE MILLERS RIVER BASIN}

Analytical results obtained from the PISCES samplers make possible the first survey of fish exposure to PCB concentration over the entire Millers River and its tributary, the Otter River. Fish receive much of their PCB burden from the food web, and food webs that start in bacteria or plant material receive PCBs initially by absorption through cell membranes from the dissolved phase. Since PISCES samplers concentrate PCBs from the dissolved phase, PISCES sampler results can be used to estimate dissolved-phase exposure.

PCB concentrations in the PISCES samplers are related to $\mathrm{PCB}$ concentrations in the water by the formula:

$$
C_{w}=M_{s} /(S t)
$$

where $C_{w}$ is the concentration of the chemical in the water, $M_{s}$ is the mass of the chemical accumulated by the sampler over the exposure time $(t)$, and $S$ is the sampling rate term, a function of temperature and membrane size (Litten and others, 1993). For $M_{s}$ in units of nanograms, $C_{w}$ in units of nanograms per liter, $t$ in days, and temperature in degrees Kelvin, the sampling rate $(S)$ in units of liters per day is:

$$
S=A e^{(-6591 / T+19.269)}
$$

where $A$ is surface area of membrane in centimeters, and $T$ is degrees Kelvin. This relationship was established by laboratory experiment and verified by comparing water-column grab samples to PISCES results in lakes and slow-moving streams (John Hassett, State University of New York-Syracuse, written commun., 2000).

Equation 1 was used to estimate water-column $\Sigma$ PCB concentrations from the PISCES results (table 3). The water temperatures used in the computation were averages of mean daily temperatures for the deployment period at USGS continuous-record stream gaging station 01095220 on the Stillwater River near Sterling, Mass., approximately $20 \mathrm{mi}$ southeast of the study area. Computed $\Sigma$ PCB water-column concentrations vary from less than $1 \mathrm{ng} / \mathrm{L}$, at upstream locations on the Millers River and the Otter River, to a maximum concentration of $310 \mathrm{ng} / \mathrm{L}$, on the Otter River just upstream from the confluence with the Millers River. Downstream from the confluence with the Otter River, computed water concentrations for the Millers River decrease over several miles to 10 to $20 \mathrm{ng} / \mathrm{L}$ and remain approximately constant to the confluence with the Connecticut River. The USEPA water-quality criterion for PCBs in water promulgated in 1992 is $0.044 \mathrm{ng} / \mathrm{L}$. In March 1998, the Agency reassessed PCB cancer risk from eating fish derived from PCB contaminated water and proposed changing the criterion to $0.17 \mathrm{ng} / \mathrm{L}$ (Federal Register, 1998). Both standards are low concentrations-only the upstream stations in the Millers River and the Otter River approach these criteria. Concentrations of PCBs in all of the reaches downstream from the maximum pattern change (between $\mathrm{O}-36.2$ and 0-35.2) are at levels that could lead to fish body burdens of PCBs that would be of concern for fish consumption. 


\section{SUMMARY AND CONCLUSIONS}

Passive samplers were used successfully in water-column deployment at 31 stations to define likely PCB source areas and exposure of fish to dissolved PCBs in the Millers River Basin. The rate of the PCB absorption by the samplers was greater during the summer than in the fall, when apparent dilution of water-column concentrations of PCBs by high flow and low water temperature decreased PCB transport across the semipermiable membranes of the samplers.

Summer results yielded consistent concentration and congener-pattern data, from which a conceptual model of PCB contamination, transport, and partitioning in the Millers River Basin was developed.

Comparison of $\mathrm{PCB}$ congener patterns indicated that a historical release point of PCBs in the Millers River Basin likely occurred on the Otter River at the upstream margin of Baldwinville, Mass. Increasing water-column concentrations with distance downstream from Baldwinville were compatible with a current (1999) source in streambed sediments in the wetland reach downstream from Baldwinville, to which the PCBs are hypothesized to have partitioned after their original introduction into the Otter River and from which PCBs are released to the water now that the original discharge has ceased or greatly decreased.

Substantial decreases in total concentrations of all targeted PCB congeners ( $\mathrm{PCB}$ ) in the Millers River downstream from the highest concentration station, on the Otter River, likely were caused by dilution with water from the relatively uncontaminated upstream Millers River, and by volatilization of PCBs in steep-gradient reaches. A relatively constant concentration of PCBs in the reach of the Millers River from river mile 20 to river mile 8 likely results from decreased volatilization rates in that relatively lowgradient reach. Resupply of PCBs to the water column from contaminated streambed sediments also may occur and tend to balance any loss to the atmosphere. A second high-gradient reach in the lower 8 miles of the Millers River before its confluence with the Connecticut River was also associated with decrease in dissolved PCB concentration. Volatilization as a loss mechanism was supported by weathering characteristics of the congener pattern in the reaches where concentration decreases occurred. Congener concentration and weathering-pattern data would not support hypothesized additional PCB sources to the Millers River, other than streambed sediments, in the reach downstream from the Birch Hill Dam.

Substantial exposure of fish food webs to dissolved PCB concentrations occurred throughout much of the Millers River Basin. Because the apparent source of PCBs discharged was upstream on the Otter River, fish in a large number of river miles downstream (more than $30 \mathrm{mi}$ ) had summer-time PCB exposures that may result in high concentrations of PCBs in fish.

\section{REFERENCES}

Barron, M.G., 1990, Bioconcentration: Environmental Science and Technology, v. 24, p. 1612-1618.

Coles, J.F., 1998, Organochlorine compounds in fish tissue from the Connecticut, Housatonic, and Thames River Basin Study unit, 1992-94: U.S. Geological Survey Water-Resources Investigations Report 98-4075, 23 p.

Eganhouse, R., and Gossett, R.W., 1991, Sources and magnitude of bias associated with determination of polychlorinated biphenyls in environmental samples: Analytical Chemistry, v. 63, p. 2130-2137.

Federal Register, 1998, Water quality standards/ establishment of numeric criteria for priority toxic pollutants/states' compliance-revision of polychlorinated biphenyls (PCBs) criteria: Environmental Protection Agency, v. 63, no. 63, p. 16182-16188.

Gay, F.B., and Frimpter, M.H., 1985, Distribution of polychlorinated biphenyls in the Housatonic River and adjacent aquifer, Massachusetts: U.S. Geological Survey Water-Supply Paper 2266, $26 \mathrm{p}$.

Litten, S., Mead, B., and Hassett, J., 1993, Application of passive samplers (PISCES) to locating a source of PCBs on the Black River, New York: Environmental Toxicology and Chemistry, v. 12, p. 639-647.

Mackay, D., Wan-Ying Shiu, and Kuo-Ching Ma, 1992, Illustrated Handbook of Physical-Chemical Properties and Environmental fate for Organic Chemicals, v. 1, Monoaromatic Hydrocarbons, Chlorobenzenes and PCBs: Chelsea, Mich., Lewis Publishers, 697 p.

Massachusetts Department of Environmental Management, Division of Water Resources, 1978 (updated March 1983), A guide to public lakes, ponds and reservoirs of Massachusetts: Massachusetts Department of Environmental Management, $129 \mathrm{p}$.

Massachusetts Department of Environmental Quality Engineering, Division of Water Pollution Control, 1974, Millers River 1973 Water Quality Analysis: Westborough, Mass., Massachusetts Department of Environmental Quality Engineering, 1 p. 
1976, Compilation of lakes, ponds, and reservoirs relative to the Massachusetts Lake Classification Program: Westborough, Mass., Massachusetts Department of Environmental Quality Engineering, $124 \mathrm{p}$.

Massachusetts Division of Water Pollution Control, 1980, The Millers River Basin 1979 water quality and time of travel survey data: Westborough Mass., Massachusetts Division of Water Pollution Control, $103 \mathrm{p}$.

Parker, G.W., and Gay, F.B., 1987, A procedure for cstimating reaeration coefficients for Massachusetts streams: U.S. Geological Survey Water-Resources Investigations Report 86-4111, 34 p.

Rantalainen, A.L., Ikonomou, M.G., and Rogers, I.H., 1998, Lipid-containing semipermeable membrane devices (SPMDs) as concentrators of toxic chemicals in the lower Fraser River, Vancouver, British Columbia: Chemosphere, v. 37, p. 1119-1138.

Safe, S., 1994, Polychlorinated biphenyls (PCBs)Environmental impact, biochemical and toxic responses, and implications for risk assessment: Critical Reviews in Toxicology, v. 4, p. 87-149.

Schulz, D.E., Petrick, G., and Duinker, J.C., 1989, Complete characterization of polychlorinated biphenyl congeners in commercial Aroclor and Clophen mixture by multidimensional gas chromatography-electron capture detection: Environmental Science and Technology, v. 23 , p. 852-859.
U.S. Army Corps of Engineers, 1991, Birch Hill Dam Reservoir PCB investigation, Phase I: Waltham, Mass., Department of the Army, New England Division, Corps of Engineers with support from the Waterways Experiment Station, variously paginated.

1993, Birch Hill Dam, Phase I-Limited Site Investigation Report: Waltham, Mass., Department of the Army, New England Division, Corps of Engineers, variously paginated, 10 appendixes.

1995, Birch Hill Reservoir PCB Investigation-Phase II: Waltham, Mass., Hydraulics and Water Quality Branch, Water Control Division, Engineering Directorate, Department of the Army, New England Division, Corps of Engineers, variously paginated.

U.S. Environmental Protection Agency, 1998, Office of Solid Waste and Emergency Response: Test Methods for Solid Wastes, SW-846, variously paginated.

Wandle, S.W., Jr., 1984, Gazetteer of hydrologic characteristics of streams in MassachusettsConnecticut River Basin: U.S. Geological Survey Water-Resources Investigations Report 84-4282, 110 p.

Willman, E.J., Manchester-Neesvig, J.B., and Armstrong, D.E., 1997, Influence of ortho-substitution on patterns of PCB accumulation in sediment, plankton, and fish in a freshwater estuary: Environmental Science and Technology, v. 31, p. 3712-3718. 
APPENDIX A: Polychlorinated Biphenyl Congener Names and International Union of Pure and Applied Chemistry (IUPAC) Numbers in Gas-Chromatograph Domain Order 
Appendix A. Polychlorinated biphenyl congener names and International Union of Pure and Applied Chemistry (IUPAC) numbers in gas-chromatograph domain order

\begin{tabular}{|c|c|c|c|c|c|}
\hline Domain & IUPAC No. & Congener name & Domain & IUPAC No. & Congener name \\
\hline 1 & 4 & 2,2'-Dichlorobiphenyl & 30 & 56 & 2,3,3',4'-Tetrachlorobiphenyl \\
\hline 1 & 10 & 2,6-Dichlorobiphenyl & 30 & 60 & 2,3,4,4'-Tetrachlorobiphenyl \\
\hline 2 & 7 & 2,4-Dichlorobiphenyl & 31 & 77 & 3,3',4,4'-Tetrachlorobiphenyl \\
\hline 2 & 9 & 2,5-Dichlorobiphenyl & 32 & 91 & 2,2',3,4',6-Pentachlorobiphenyl \\
\hline 3 & 6 & 2,3'-Dichlorobiphenyl & 33 & 92 & 2,2',3,5,5'-Pentachlorobiphenyl \\
\hline 4 & 5 & 2,3-Dichlorobiphenyl & 34 & 84 & 2,2',3,3',6-Pentachlorobiphenyl \\
\hline 4 & 8 & 2,4'-Dichlorobiphenyl & 35 & 90 & $2,2^{\prime}, 3,4^{\prime}, 5$-Pentachlorobiphenyl \\
\hline 5 & 15 & 4,4'-Dichlorobiphenyl & 35 & 101 & 2,2',4,5,5'-Pentachlorobiphenyl \\
\hline 6 & 19 & 2,2',6-Trichlorobiphenyl & 35 & 89 & 2,2',3,4,6'-Pentachlorobiphenyl \\
\hline 7 & 18 & $2,2^{\prime}, 5$-Trichlorobiphenyl & 36 & 99 & $2,2^{\prime}, 4,4^{\prime}, 5$-Pentachlorobiphenyl \\
\hline 8 & 17 & 2,2',4-Trichlorobiphenyl & 37 & 83 & $2,2^{\prime}, 3,3^{\prime}, 5$-Pentachlorobiphenyl \\
\hline 9 & 24 & 2,3,6-Trichlorobiphenyl & 37 & 108 & $2,3,3^{\prime}, 4,5^{\prime}$-Pentachlorobiphenyl \\
\hline 9 & 27 & 2,3',6-Trichlorobiphenyl & 38 & 97 & $2,2^{\prime}, 3^{\prime}, 4,5$-Pentachlorobiphenyl \\
\hline 10 & 16 & 2,2',3-Trichlorobiphenyl & 38 & 86 & 2,2',3,4,5-Pentachlorobiphenyl \\
\hline 10 & 32 & 2,4',6-Trichlorobiphenyl & 39 & 87 & 2,2 ',3,4,5'-Pentachlorobiphenyl \\
\hline 11 & 26 & 2,3',5-Trichlorobiphenyl & 39 & 115 & 2,3,4,4',6-Pentachlorobiphenyl \\
\hline 12 & 25 & 2,3',4-Trichlorobiphenyl & 39 & 116 & 2,3,4,5,6-Pentachlorobiphenyl \\
\hline 13 & 31 & 2,4',5-Trichlorobiphenyl & 40 & 85 & 2,2',3,4,4'-Pentachlorobiphenyl \\
\hline 14 & 28 & $2,4,4^{\prime}$-Trichlorobiphenyl & 40 & 120 & 2,3',4,5,5'-Pentachlorobiphenyl \\
\hline 15 & 33 & 2',3,4-Trichlorobiphenyl & 41 & 110 & 2,3,3',4',6-Pentachlorobiphenyl \\
\hline 15 & 20 & 2,3,3'-Trichlorobiphenyl & 42 & 82 & 2,2',3,3',4-Pentachlorobiphenyl \\
\hline 15 & 21 & 2,3,4-Trichlorobiphenyl & 43 & 114 & 2,3,4,4',5-Pentachlorobiphenyl \\
\hline 16 & 22 & 2,3,4'-Trichlorobiphenyl & 44 & 122 & 2',3,3'4,5-Pentachlorobiphenyl \\
\hline 17 & 37 & 3,4,4'-Trichlorobiphenyl & 45 & 126 & $3,3^{\prime}, 4,4^{\prime}, 5$-Pentachlorobiphenyl \\
\hline 18 & 53 & $2,2^{\prime}, 5,6^{\prime}$-Tetrachlorobiphenyl & 46 & 136 & $2,2^{\prime}, 3,3^{\prime}, 6,6^{\prime}$-Hexachlorobiphenyl \\
\hline 19 & 51 & $2,2^{\prime}, 4,6^{\prime}$-Tetrachlorobiphenyl & 47 & 151 & $2,2^{\prime}, 3,5,5^{\prime}, 6$-Hexachlorobiphenyl \\
\hline 20 & 45 & 2,2 ',3,6-Tetrachlorobiphenyl & 48 & 144 & $2,2^{\prime}, 3,4,5^{\prime}, 6-$ Hexachlorobiphenyl \\
\hline 21 & 46 & $2,2^{\prime}, 3,6^{\prime}$-Tetrachlorobiphenyl & 48 & 135 & $2,2^{\prime}, 3,3^{\prime}, 5,6^{\prime}$-Hexachlorobiphenyl \\
\hline 22 & 52 & $2,2^{\prime}, 5,5^{\prime}$-Tetrachlorobiphenyl & 49 & 149 & $2,2^{\prime}, 3,4^{\prime}, 5^{\prime}, 6$-Hexachlorobiphenyl \\
\hline 22 & 73 & 2,3',5',6-Tetrachlorobiphenyl & 49 & 139 & $2,2^{\prime}, 3,4,4^{\prime}, 6-$ Hexachlorobiphenyl \\
\hline 23 & 49 & 2,2 ',4,5'-Tetrachlorobiphenyl & 50 & 134 & 2,2',3,3',5,6-Hexachlorobiphenyl \\
\hline 23 & 43 & 2,2',3,5-Tetrachlorobiphenyl & 50 & 143 & $2,2^{\prime}, 3,4,5,6^{\prime}-$ Hexachlorobiphenyl \\
\hline 24 & 47 & $2,2^{\prime} 4,4^{\prime}$-Tetrachlorobiphenyl & 51 & 131 & $2,2^{\prime}, 3,3^{\prime}, 4,6-$ Hexachlorobiphenyl \\
\hline 24 & 48 & 2,2',4,5-Tetrachlorobiphenyl & 51 & 142 & $2,2 ', 3,4,5,6$-Hexachlorobiphenyl \\
\hline 24 & 75 & 2,4,4',6-Tetrachlorobiphenyl & 52 & 146 & $2,2^{\prime}, 3,4^{\prime}, 5,5^{\prime}$-Hexachlorobiphenyl \\
\hline 25 & 44 & $2,2^{\prime}, 3,5^{\prime}$-Tetrachlorobiphenyl & 53 & 123 & 2',3,4,4',5-Pentachlorobiphenyl \\
\hline 26 & 42 & 2,2 ',3,4'-Tetrachlorobiphenyl & 54 & 118 & 2,3',4,4',5-Pentachlorobiphenyl \\
\hline 26 & 59 & 2,3,3',6-Tetrachlorobiphenyl & 54 & 106 & 2,3,3',4,5-Pentachlorobiphenyl \\
\hline 27 & 41 & 2,2',3,4-Tetrachlorobiphenyl & 55 & 105 & 2,3,3',4,4'-Pentachlorobiphenyl \\
\hline 27 & 71 & $2,3^{\prime}, 4^{\prime}, 6-$ Tetrachlorobiphenyl & 55 & 127 & 3,3',4,5,5'-Pentachlorobiphenyl \\
\hline 27 & 64 & 2,3,4',6-Tetrachlorobiphenyl & 56 & 153 & $2,2^{\prime}, 4,4^{\prime}, 5,5^{\prime}$-Hexachlorobiphenyl \\
\hline 27 & 68 & $2,3^{\prime}, 4,5^{\prime}$-Tetrachlorobiphenyl & 57 & 132 & $2,2^{\prime}, 3,3^{\prime}, 4,6^{\prime}$-Hexachlorobiphenyl \\
\hline 28 & 40 & $2,2^{\prime}, 3,3^{\prime}$-Tetrachlorobiphenyl & 57 & 168 & $2,3^{\prime}, 4,4^{\prime}, 5^{\prime}, 6-$ Hexachlorobiphenyl \\
\hline 29 & 74 & 2,4,4',5-Tetrachlorobiphenyl & 58 & 141 & $2,2^{\prime}, 3,4,5,5^{\prime}$-Hexachlorobiphenyl \\
\hline 29 & 61 & 2,3,4,5-Tetrachlorobiphenyl & 59 & 137 & $2,2^{\prime}, 3,4,4^{\prime}, 5$-Hexachlorobiphenyl \\
\hline
\end{tabular}


Appendix A. Polychlorinated biphenyl congener names and International Union of Pure and Applied Chemistry (IUPAC) numbers in gas-chromatograph domain order-Continued

\begin{tabular}{|c|c|c|}
\hline Domain & IUPAC No. & Congener name \\
\hline 60 & 138 & 2,2',3,4,4',5'-Hexachlorobiphenyl \\
\hline 60 & 163 & $2,3,3^{\prime}, 4^{\prime}, 5,6-$ Hexachlorobiphenyl \\
\hline 60 & 164 & $2,3,3^{\prime}, 4^{\prime}, 5^{\prime}, 6$-Hexachlorobiphenyl \\
\hline 61 & 158 & $2,3,3^{\prime}, 4,4^{\prime}, 6-$ Hexachlorobiphenyl \\
\hline 61 & 160 & $2,3,3^{\prime}, 4,5,6$-Hexachlorobiphenyl \\
\hline 62 & 129 & $2,2^{\prime}, 3,3^{\prime}, 4,5-$ Hexachlorobiphenyl \\
\hline 63 & 128 & $2,2^{\prime}, 3,3$ ',4,4'-Hexachlorohiphenyl \\
\hline 64 & 156 & $2,3,3^{\prime}, 4,4^{\prime}, 5$-Hexachlorobiphenyl \\
\hline 65 & 157 & $2,3,3^{\prime}, 4,4^{\prime}, 5^{\prime}$-Hexachlorobiphenyl \\
\hline 66 & 179 & $2,2^{\prime}, 3,3^{\prime}, 5,6,6^{\prime}$-Heptachlorobiphenyl \\
\hline 67 & 176 & $2,2^{\prime}, 3,3^{\prime}, 4,6,6^{\prime}$-Heptachlorobiphenyl \\
\hline 68 & 178 & $2,2^{\prime}, 3,3^{\prime}, 5,5^{\prime}, 6-$ Heptachlorobiphenyl \\
\hline 69 & 175 & $2,2^{\prime}, 3,3^{\prime}, 4,5^{\prime}, 6-$ Heptachlorobiphenyl $^{\prime}$ \\
\hline 70 & 187 & $2,2^{\prime}, 3,4^{\prime}, 5,5^{\prime}, 6$-Heptachlorobiphenyl \\
\hline 70 & 182 & $2,2^{\prime}, 3,4,4^{\prime}, 5,6^{\prime}$-Heptachlorobiphenyl \\
\hline 71 & 183 & $2,2^{\prime}, 3,4,4^{\prime}, 5^{\prime}, 6$-Heptachlorobiphenyl \\
\hline 72 & 185 & $2,2^{\prime}, 3,4,5,5^{\prime}, 6$-Heptachlorobiphenyl \\
\hline 73 & 174 & $2,2^{\prime}, 3,3^{\prime}, 4,5,6^{\prime}-$ Heptachlorobiphenyl $^{\prime}$ \\
\hline 73 & 181 & $2,2^{\prime}, 3,4,4^{\prime}, 5,6$-Heptachlorobiphenyl \\
\hline 74 & 177 & $2,2^{\prime}, 3,3^{\prime}, 4^{\prime}, 5,6$-Heptachlorobiphenyl \\
\hline
\end{tabular}

\begin{tabular}{|c|c|c|}
\hline Domain & IUPAC No. & Congener name \\
\hline 75 & 171 & $2,2^{\prime}, 3,3^{\prime}, 4,4^{\prime}, 6-$ Heptachlorobiphenyl \\
\hline 76 & 173 & $2,2^{\prime}, 3,3^{\prime}, 4,5,6$-Heptachlorobiphenyl \\
\hline 77 & 172 & $2,2^{\prime}, 3,3^{\prime}, 4,5,5^{\prime}-$ Heptachlorobiphenyl \\
\hline 77 & 192 & $2,3,3^{\prime}, 4,5,5^{\prime}, 6-$ Heptachlorobiphenyl \\
\hline 78 & 180 & $2,2^{\prime}, 3,4,4^{\prime}, 5,5^{\prime}$-Heptachlorobiphenyl \\
\hline 79 & 193 & $2,3,3^{\prime}, 4^{\prime}, 5,5^{\prime}, 6-$ Heptachlorobiphenyl \\
\hline 80 & 170 & $2,2^{\prime}, 3,3^{\prime}, 4,4^{\prime}, 5$-Heptachlorobiphenyl \\
\hline 80 & 190 & $2,3,3^{\prime}, 4,4^{\prime}, 5,6-$ Heptachlorobiphenyl \\
\hline 81 & 202 & $2,2^{\prime}, 3,3^{\prime}, 5,5^{\prime}, 6,6^{\prime}$-Octachlorobiphenyl \\
\hline 82 & 201 & $2,2^{\prime}, 3,3^{\prime}, 4,5^{\prime}, 6,6^{\prime}$-Octachlorobiphenyl \\
\hline 83 & 200 & $2,2^{\prime}, 3,3^{\prime}, 4,5,6,6^{\prime}$-Octachlorobiphenyl \\
\hline 84 & 198 & $2,2^{\prime}, 3,3^{\prime}, 4,5,5^{\prime}, 6$-Octachlorobiphenyl \\
\hline 85 & 196 & $2,2^{\prime}, 3,3^{\prime}, 4,4^{\prime}, 5^{\prime}, 6$-Octachlorobiphenyl \\
\hline 85 & 203 & $2,2^{\prime}, 3,4,4^{\prime}, 5,5^{\prime}, 6$-Octachlorobiphenyl \\
\hline 86 & 195 & $2,2^{\prime}, 3,3^{\prime}, 4,4^{\prime}, 5,6$-Octachlorobiphenyl \\
\hline 87 & 194 & $2,2^{\prime}, 3,3^{\prime}, 4,4^{\prime}, 5,5^{\prime}$-Octachlorobiphenyl \\
\hline 88 & 205 & $2,3,3^{\prime}, 4,4^{\prime}, 5,5^{\prime}, 6$-Octachlorobiphenyl \\
\hline 89 & 208 & $2,2^{\prime}, 3,3^{\prime}, 4,5,5^{\prime}, 6,6^{\prime}$-Nonachlorobiphenyl \\
\hline
\end{tabular}




\section{APPENDIX B: Polychlorinated Biphenyl Congeners from 31 Stations in the Millers River Basin, Massachusetts}




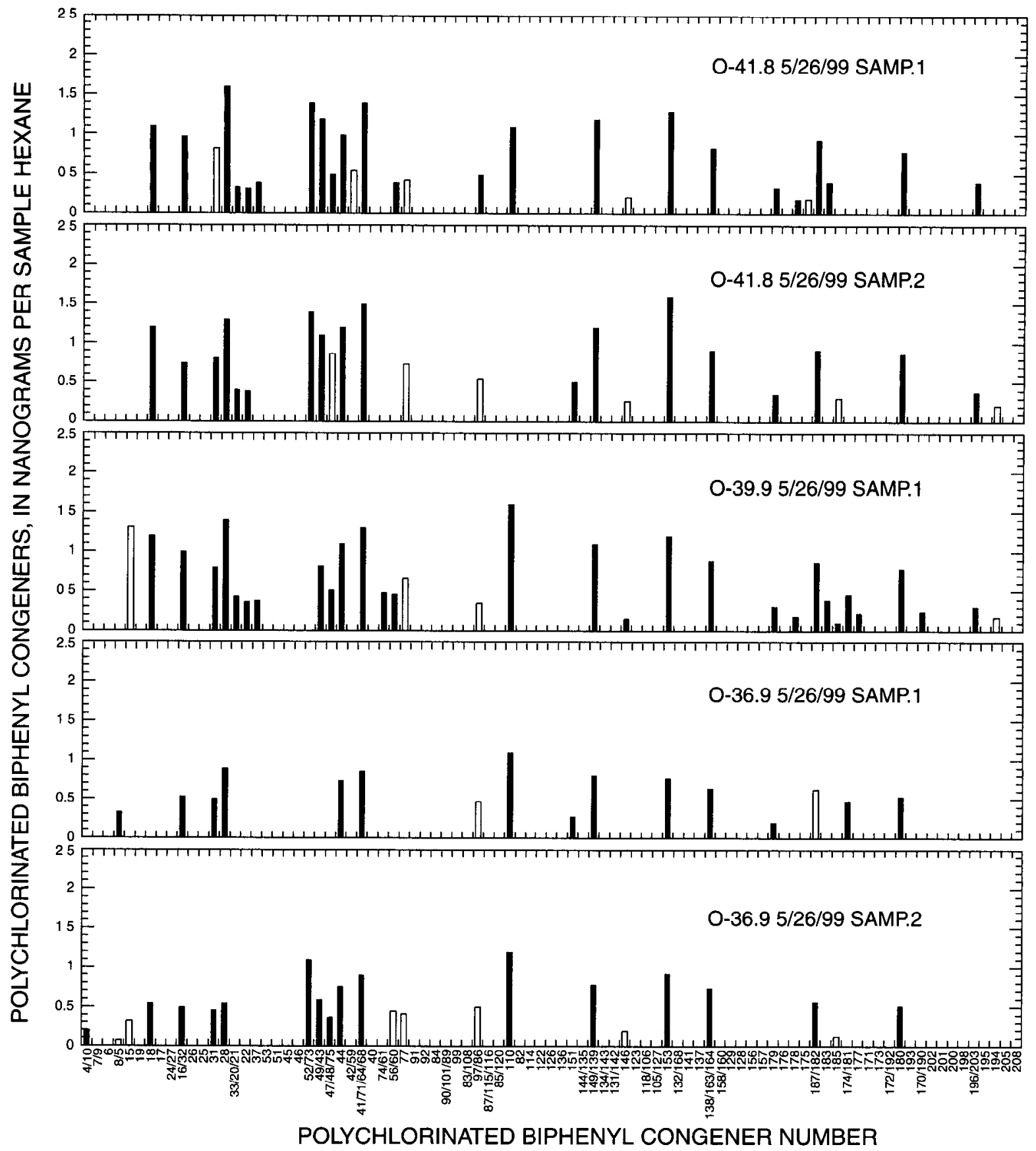

Appendix B. Polychlorinated biphenyl congeners from 31 stations in the Millers River Basin, Massachusetts. [Samples are listed in downstream order and correspond in date order to the sample listing in table 2. When more than one congener is displayed for one bar, multiple IUPAC numbers are given separated by a slash. Unfilled bars represent cases where the ratio of monitored ion molecular fragments recorded by the mass spectrometer did not pass the laboratory-ratio criterion that was established for a congener expected at a particular retention time. Designation (High Res) indicates sample was analyzed additionally by high-resolution mass spectrometry.] 


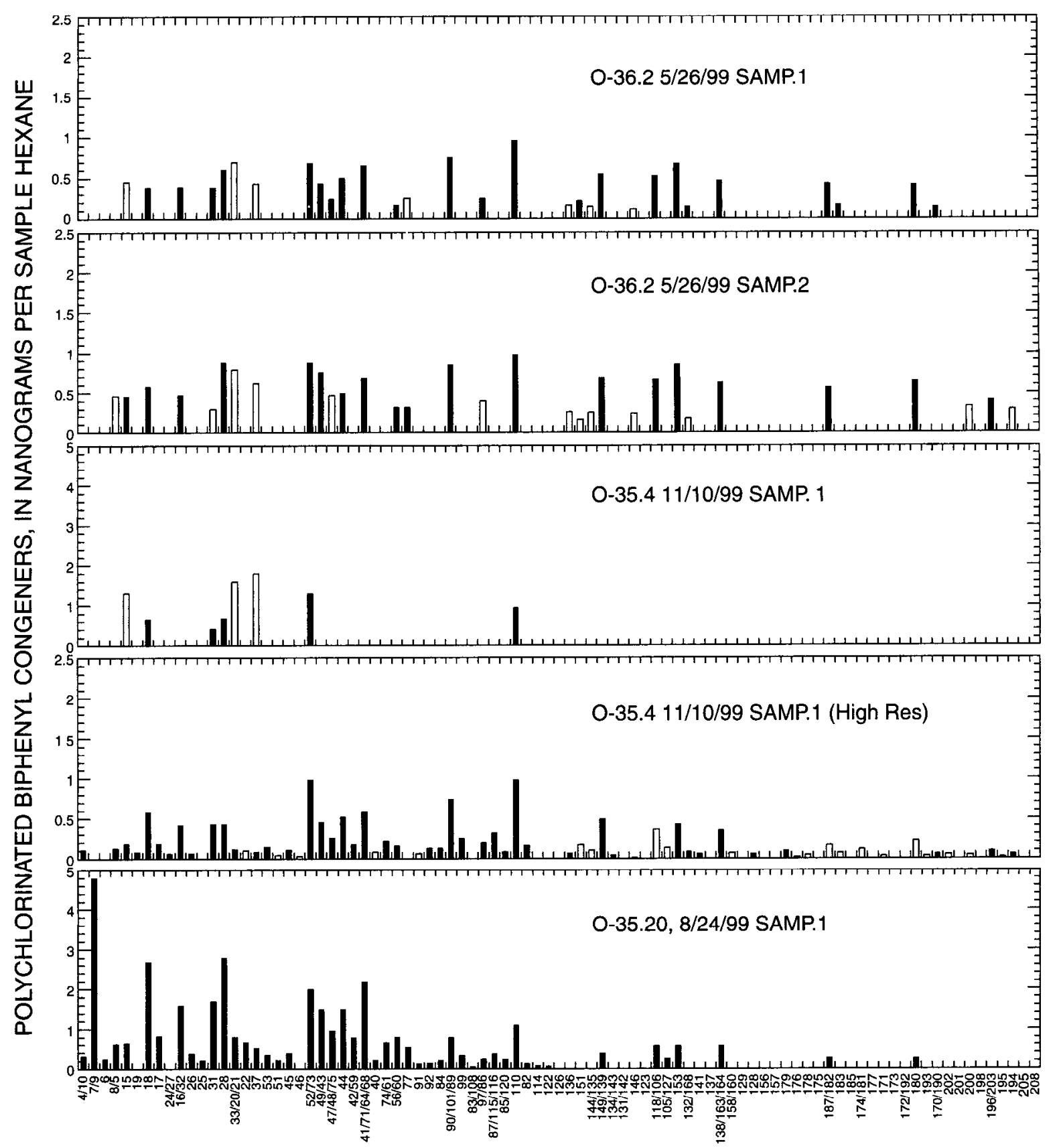

POLYCHLORINATED BIPHENYL CONGENER NUMBER

Appendix B. Polychlorinated biphenyl congeners from 31 stations in the Millers River Basin, Massachusetts. [Samples are listed in downstream order and correspond in date order to the sample listing in table 2. When more than one congener is displayed for one bar, multiple IUPAC numbers are given separated by a slash. Unfilled bars represent cases where the ratio of monitored ion molecular fragments recorded by the mass spectrometer did not pass the laboratory-ratio criterion that was established for a congener expected at a particular retention time. Designation (High Res) indicates sample was analyzed additionally by high-resolution mass spectrometry.] - Continued. 


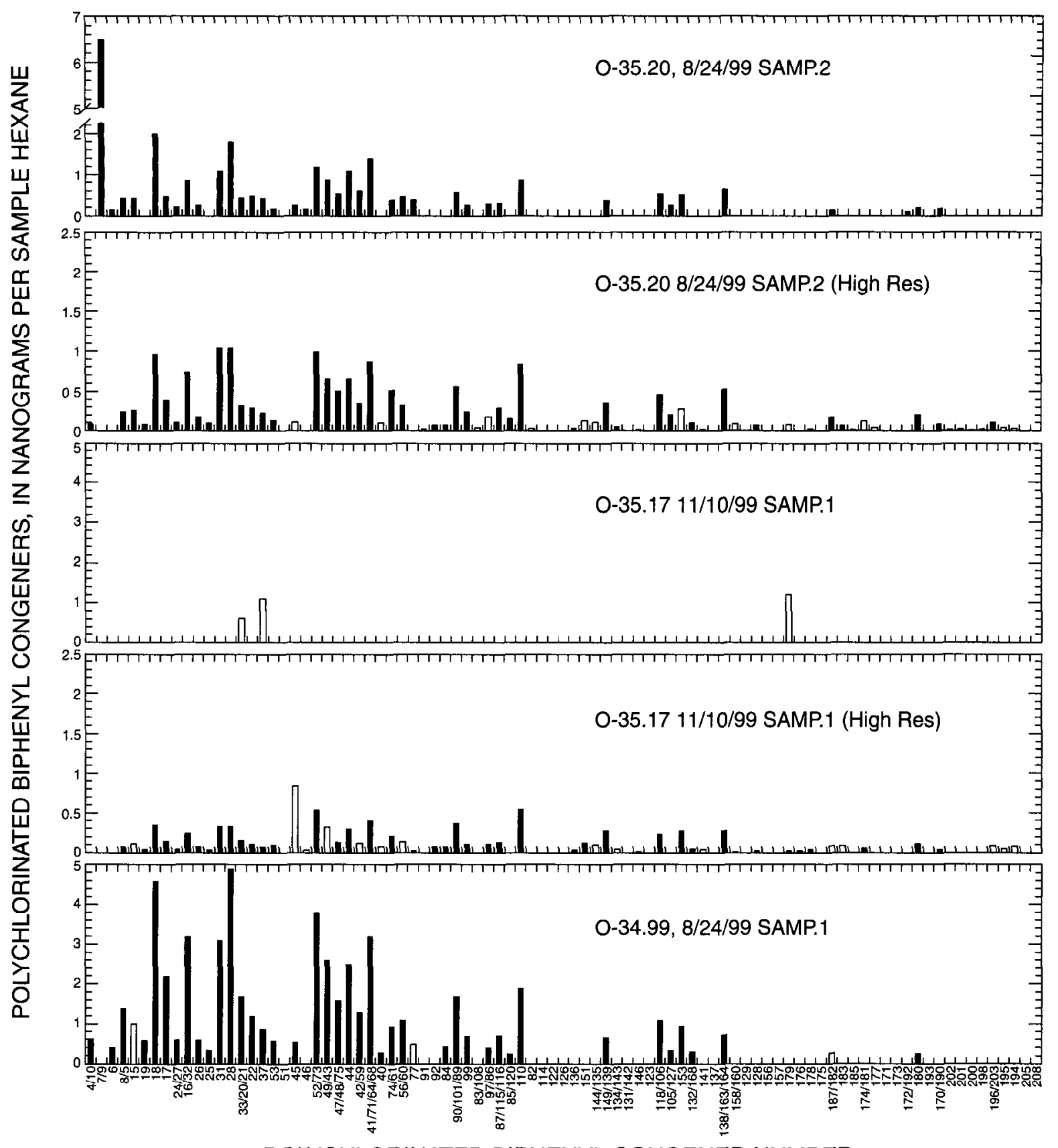

POLYCHLORINATED BIPHENYL CONGENER NUMBER

Appendix B. Polychlorinated biphenyl congeners from 31 stations in the Millers River Basin, Massachusetts.

[Samples are listed in downstream order and correspond in date order to the sample listing in table 2. When more than one congener is displayed for one bar, multiple IUPAC numbers are given separated by a slash. Unfilled bars represent cases where the ratio of monitored ion molecular fragments recorded by the mass spectrometer did not pass the laboratory-ratio criterion that was established for a congener expected at a particular retention time. Designation (High Res) indicates sample was analyzed additionally by high-resolution mass spectrometry.]-Continued. 


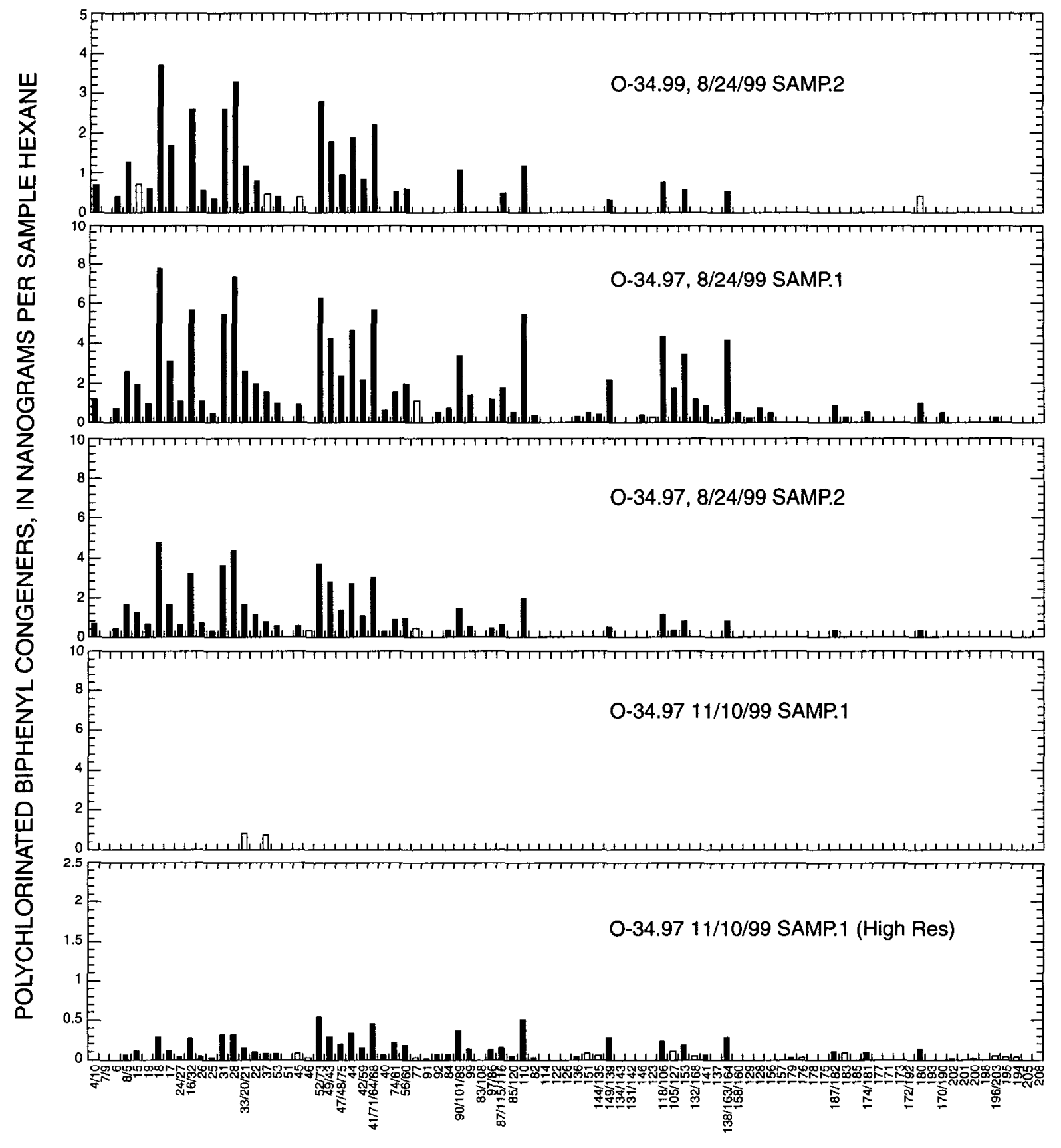

POLYCHLORINATED BIPHENYL CONGENER NUMBER

Appendix B. Polychlorinated biphenyl congeners from 31 stations in the Millers River Basin, Massachusetts. [Samples are listed in downstream order and correspond in date order to the sample listing in table 2. When more than one congener is displayed for one bar, multiple IUPAC numbers are given separated by a slash. Unfilled bars represent cases where the ratio of monitored ion molecular fragments recorded by the mass spectrometer did not pass the laboratory-ratio criterion that was established for a congener expected at a particular retention time. Designation (High Res) indicates sample was analyzed additionally by high-resolution mass spectrometry.] - Continued. 


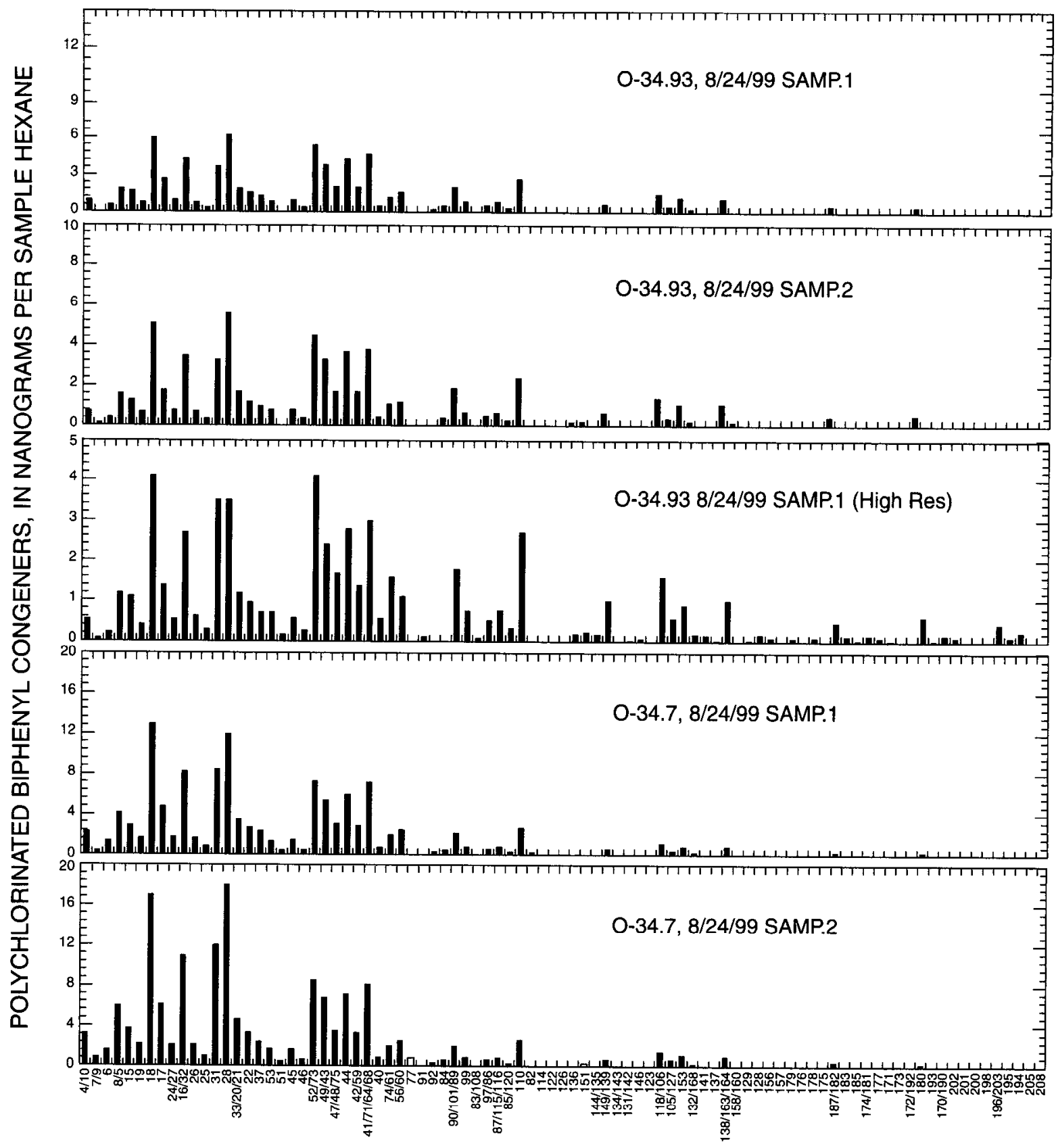

POLYCHLORINATED BIPHENYL CONGENER NUMBER

Appendix B. Polychlorinated biphenyl congeners from 31 stations in the Millers River Basin, Massachusetts. [Samples are listed in downstream order and correspond in date order to the sample listing in table 2. When more than one congener is displayed for one bar, multiple IUPAC numbers are given separated by a slash. Unfilled bars represent cases where the ratio of monitored ion molecular fragments recorded by the mass spectrometer did not pass the laboratory-ratio criterion that was established for a congener expected at a particular retention time. Designation (High Res) indicates sample was analyzed additionally by high-resolution mass spectrometry.]-Continued. 


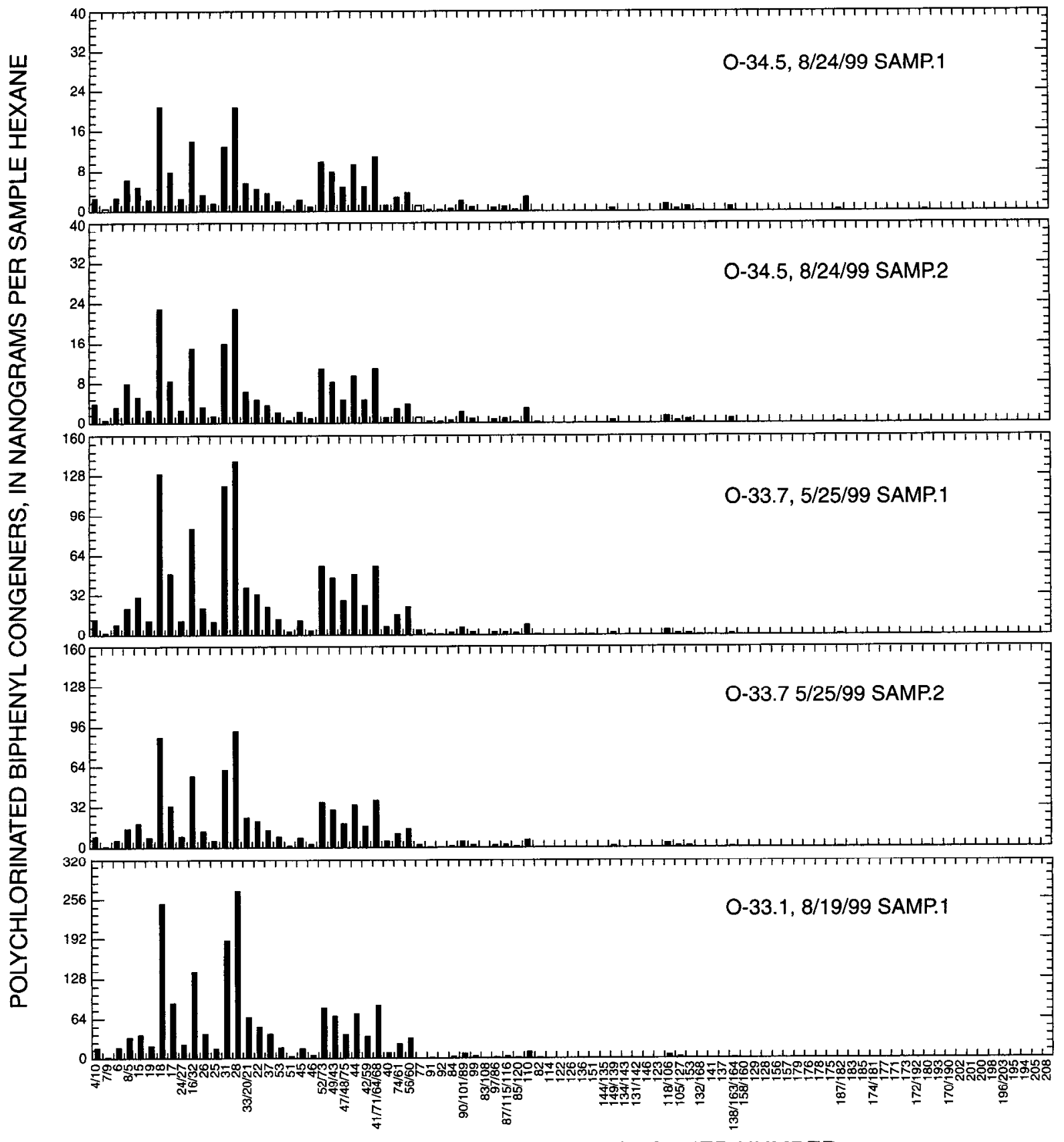

POLYCHLORINATED BIPHENYL CONGENER NUMBER

Appendix B. Polychlorinated biphenyl congeners from 31 stations in the Millers River Basin, Massachusetts. [Samples are listed in downstream order and correspond in date order to the sample listing in table 2. When more than one congener is displayed for one bar, multiple IUPAC numbers are given separated by a slash. Unfilled bars represent cases where the ratio of monitored ion molecular fragments recorded by the mass spectrometer did not pass the laboratory-ratio criterion that was established for a congener expected at a particular retention time. Designation (High Res) indicates sample was analyzed additionally by high-resolution mass spectrometry.]-Continued. 


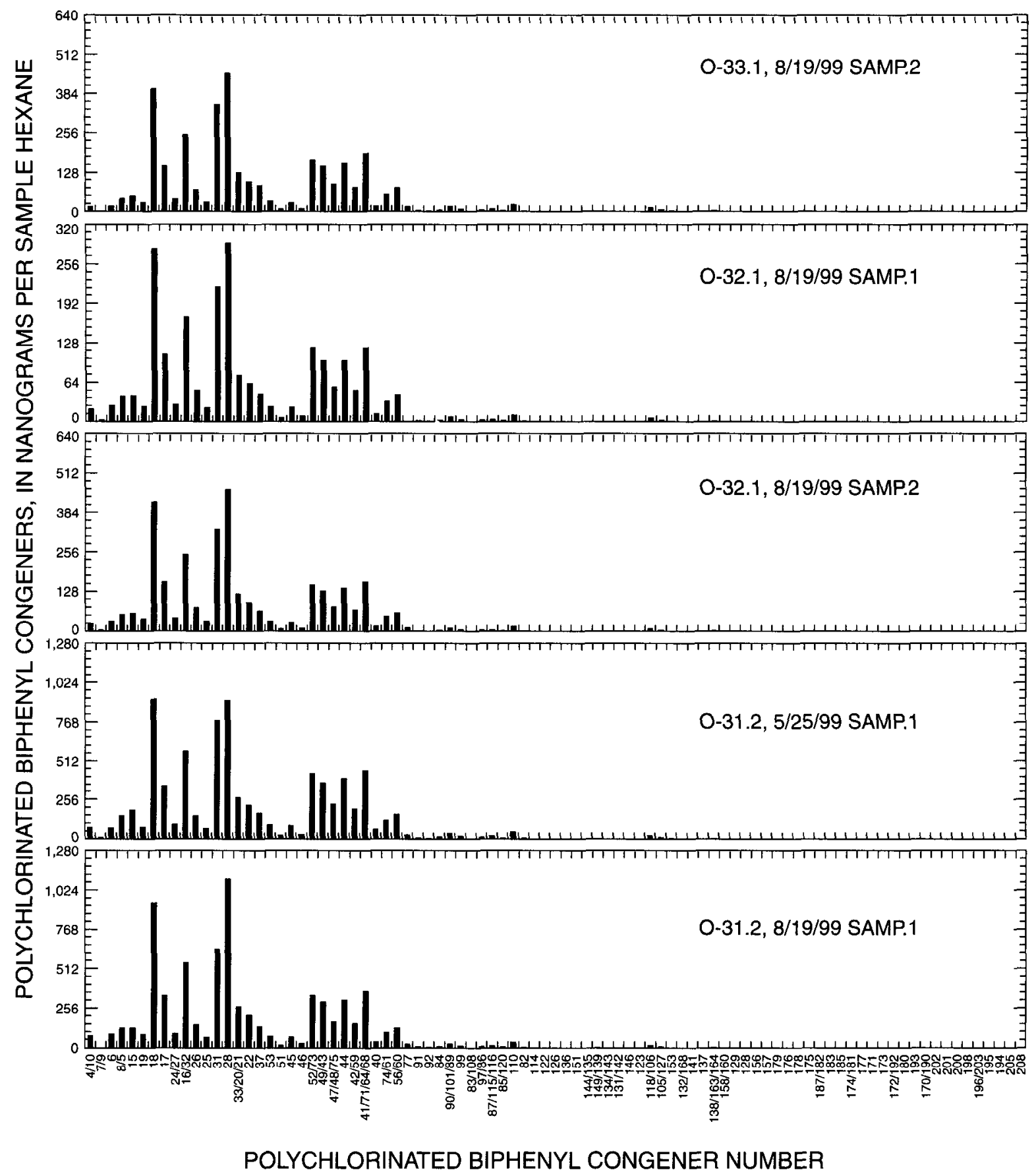

Appendix B. Polychlorinated biphenyl congeners from 31 stations in the Millers River Basin, Massachusetts. [Samples are listed in downstream order and correspond in date order to the sample listing in table 2. When more than one congener is displayed for one bar, multiple IUPAC numbers are given separated by a slash. Unfilled bars represent cases where the ratio of monitored ion molecular fragments recorded by the mass spectrometer did not pass the laboratory-ratio criterion that was established for a congener expected at a particular retention time. Designation (High Res) indicates sample was analyzed additionally by high-resolution mass spectrometry.]—Continued. 

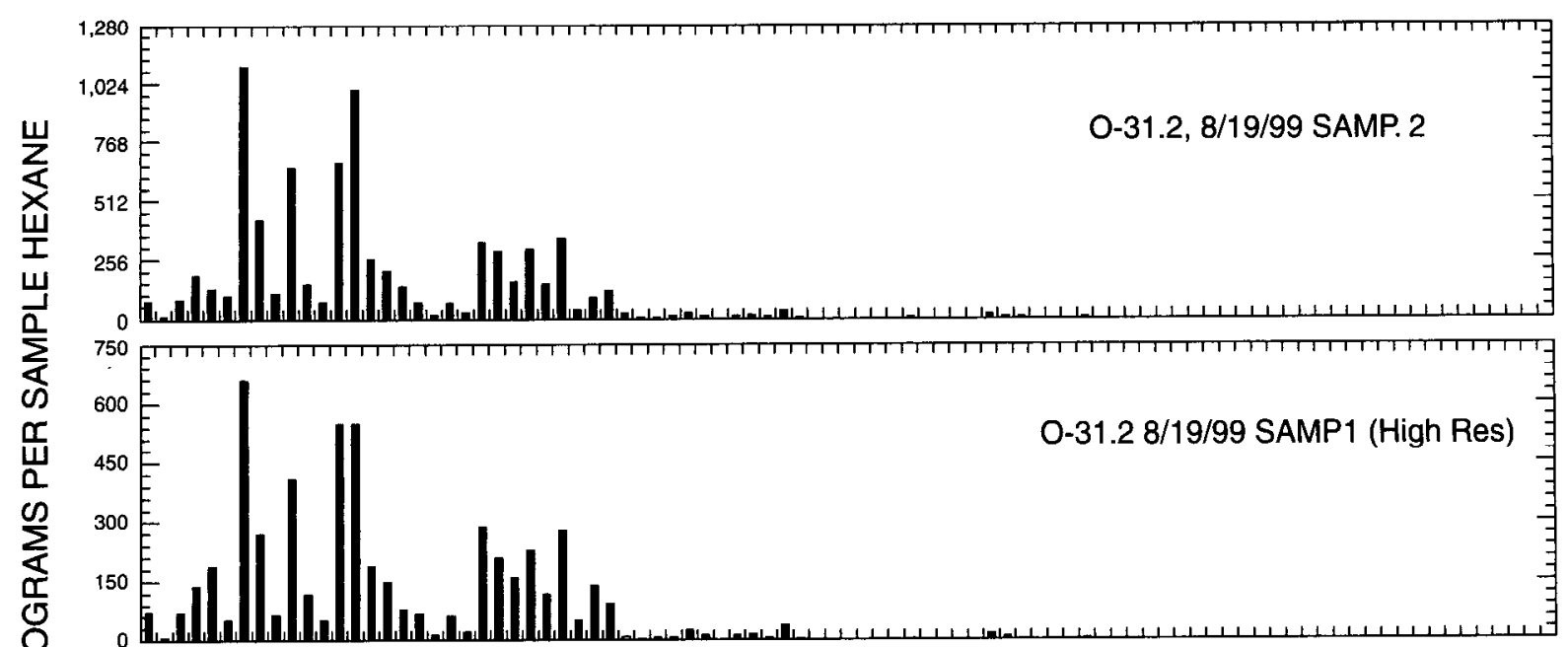

정

2.5

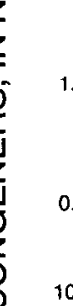

要

5

M-33.8 5/25/99 SAMP.1

$\stackrel{1}{\zeta} 99$

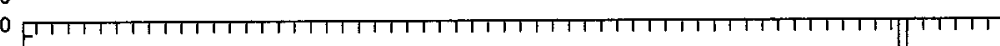

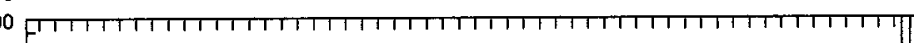

99.

$\frac{\bar{c}}{\mathrm{~m}}$

崖

至

${ }_{0} E_{1}$

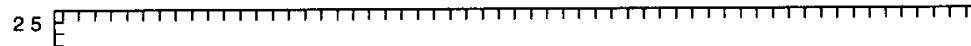

(1)

M-33.8 5/25/99 SAMP.2 (High Res)

M-33.8 5/25/99 SAMP.2

0

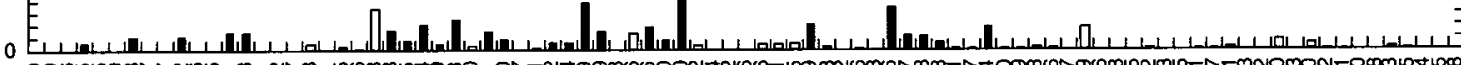

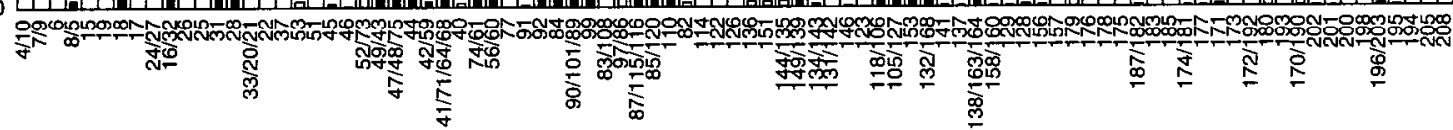

POLYCHLORINATED BIPHENYL CONGENER NUMBER

Appendix B. Polychlorinated biphenyl congeners from 31 stations in the Millers River Basin, Massachusetts. [Samples are listed in downstream order and correspond in date order to the sample listing in table 2. When more than one congener is displayed for one bar, multiple IUPAC numbers are given separated by a slash. Unfilled bars represent cases where the ratio of monitored ion molecular fragments recorded by the mass spectrometer did not pass the laboratory-ratio criterion that was established for a congener expected at a particular retention time. Designation (High Res) indicates sample was analyzed additionaliy by high-resolution mass spectrometry.]-Continued. 


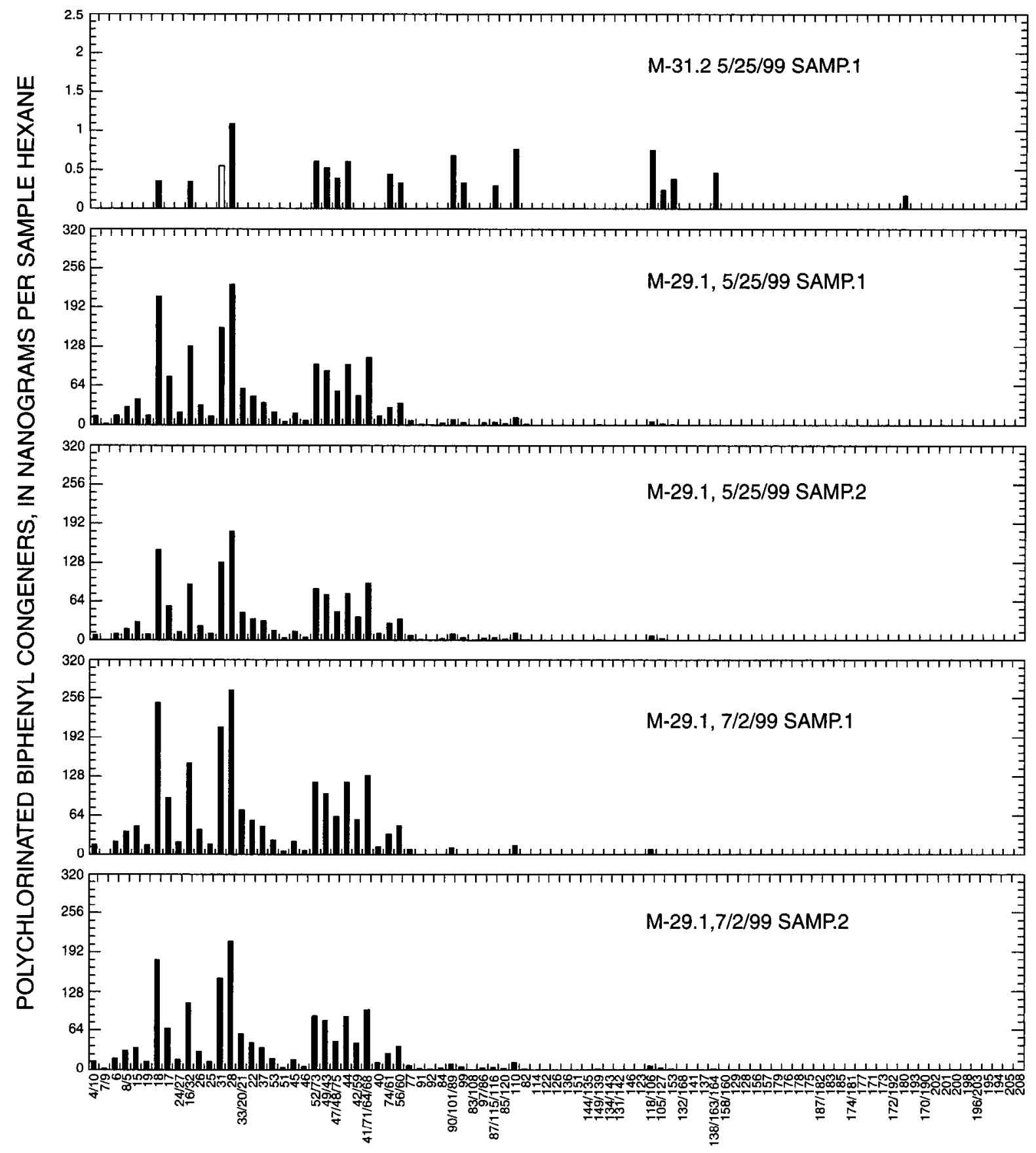

POLYCHLORINATED BIPHENYL CONGENER NUMBER

Appendix B. Polychlorinated biphenyl congeners from 31 stations in the Millers River Basin, Massachusetts. [Samples are listed in downstream order and correspond in date order to the sample listing in table 2. When more than one congener is displayed for one bar, multiple IUPAC numbers are given separated by a slash. Unfilled bars represent cases where the ratio of monitored ion molecular fragments recorded by the mass spectrometer did not pass the laboratory-ratio criterion that was established for a congener expected at a particular retention time. Designation (High Res) indicates sample was analyzed additionally by high-resolution mass spectrometry.]-Continued. 

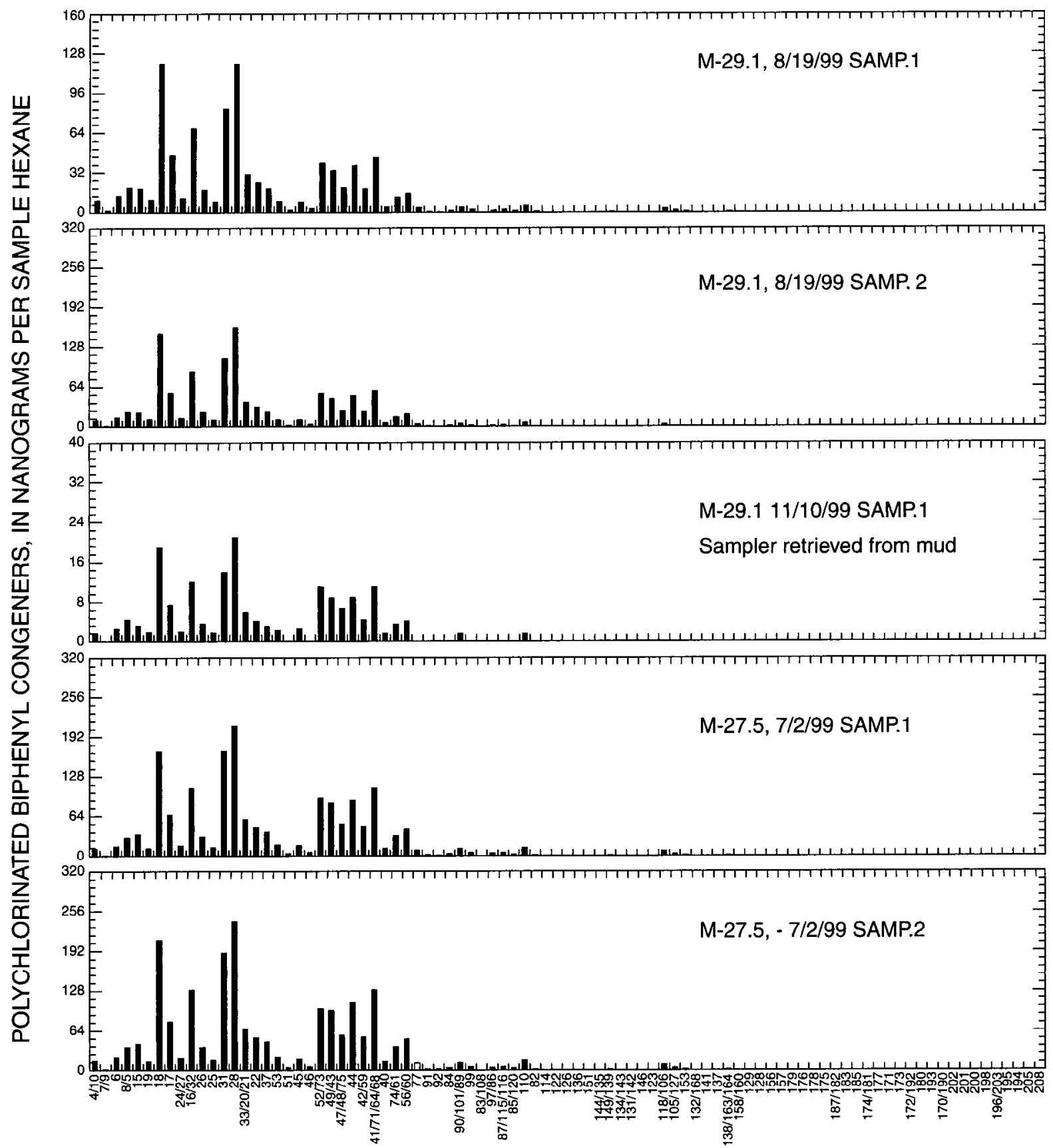

POLYCHLORINATED BIPHENYL CONGENER NUMBER

Appendix B. Polychlorinated biphenyl congeners from 31 stations in the Millers River Basin, Massachusetts. [Samples are listed in downstream order and correspond in date order to the sample listing in table 2 . When more than one congener is displayed for one bar, multiple IUPAC numbers are given separated by a slash. Unfilled bars represent cases where the ratio of monitored ion molecular fragments recorded by the mass spectrometer did not pass the laboratory-ratio criterion that was established for a congener expected at a particular retention time. Designation (High Res) indicates sample was analyzed additionally by high-resolution mass spectrometry.]-Continued. 


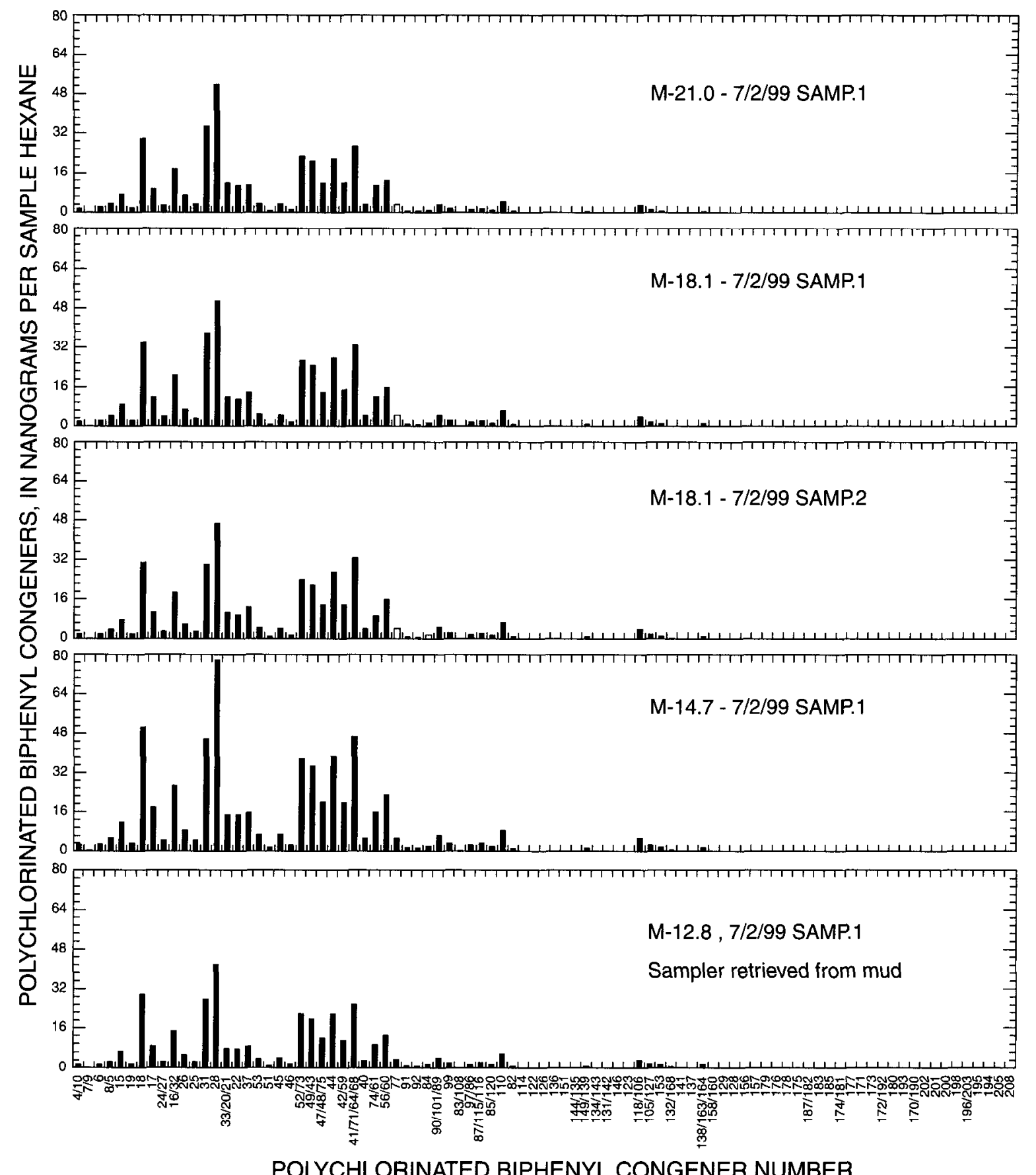

Appendix B. Polychlorinated biphenyl congeners from 31 stations in the Millers River Basin, Massachusetts. [Samples are listed in downstream order and correspond in date order to the sample listing in table 2. When more than one congener is displayed for one bar, multiple IUPAC numbers are given separated by a slash. Unfilled bars represent cases where the ratio of monitored ion molecular fragments recorded by the mass spectrometer did not pass the laboratory-ratio criterion that was established for a congener expected at a particular retention time. Designation (High Res) indicates sample was analyzed additionally by high-resolution mass spectrometry.] - Continued. 

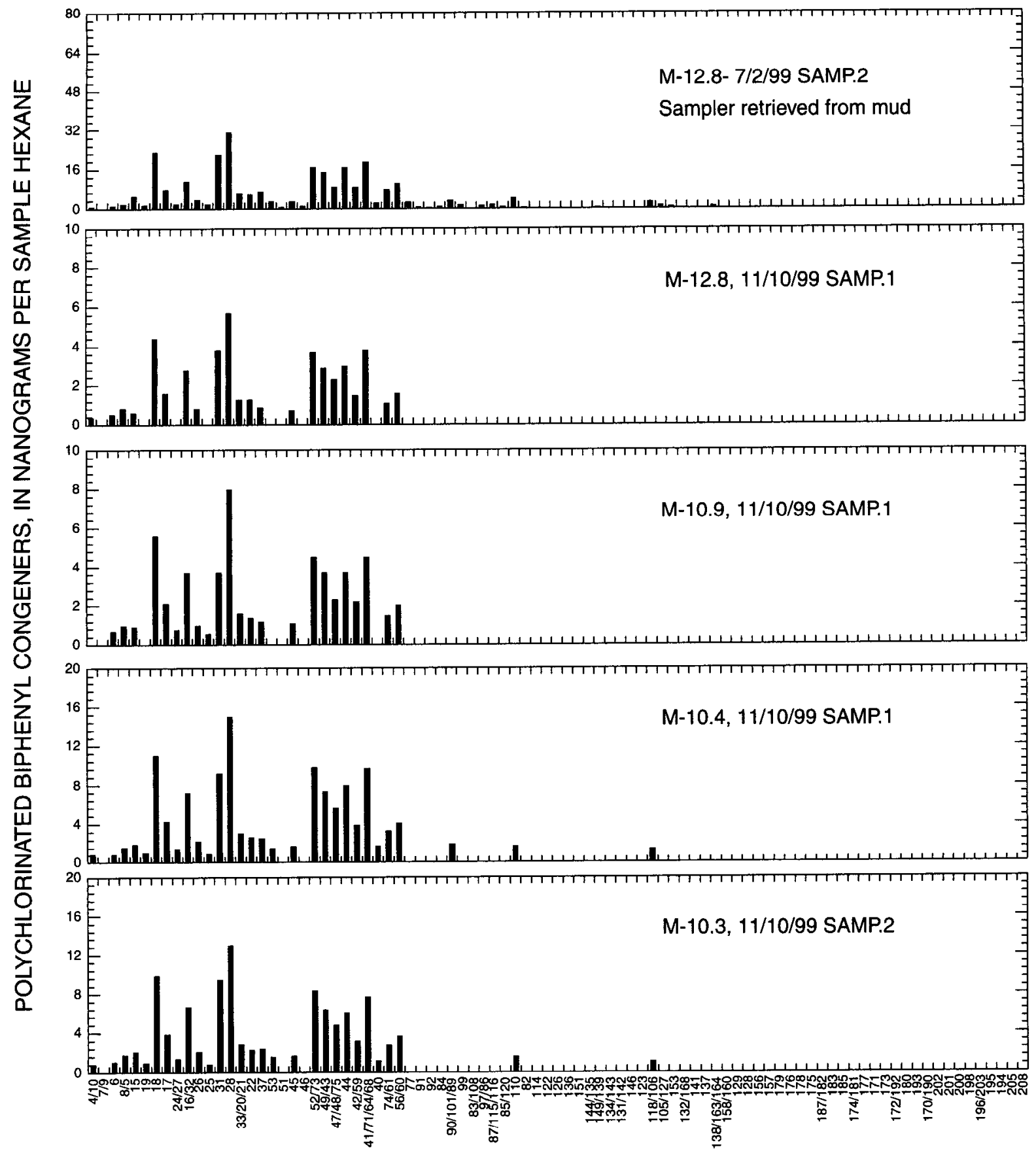

POLYCHLORINATED BIPHENYL CONGENER NUMBER

Appendix B. Polychlorinated biphenyl congeners from 31 stations in the Millers River Basin, Massachusetts. [Samples are listed in downstream order and correspond in date order to the sample listing in table 2. When more than one congener is displayed for one bar, multiple IUPAC numbers are given separated by a slash. Unfilled bars represent cases where the ratio of monitored ion molecular fragments recorded by the mass spectrometer did not pass the laboratory-ratio criterion that was established for a congener expected at a particular retention time. Designation (High Res) indicates sample was analyzed additionally by high-resolution mass spectrometry.]-Continued. 


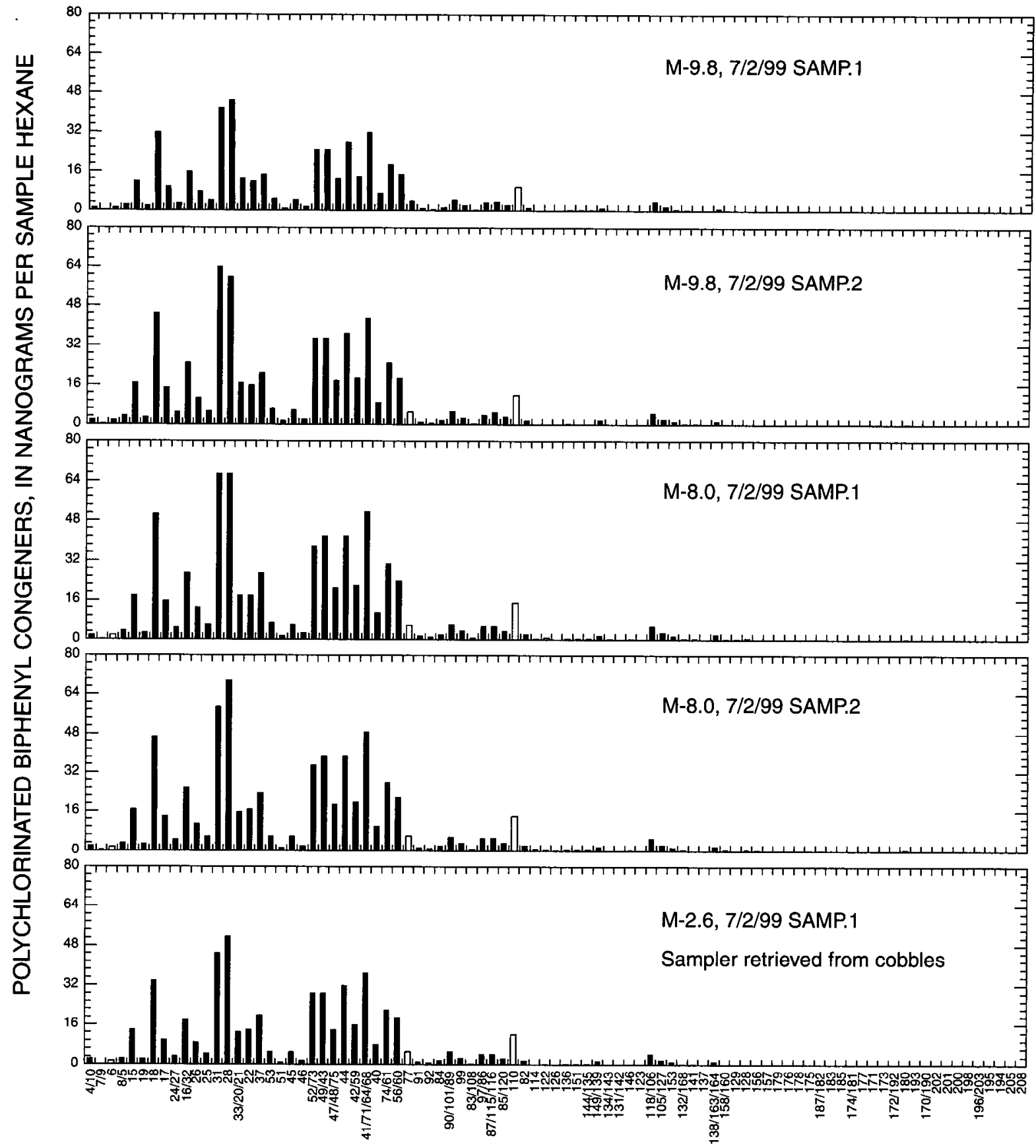

POLYCHLORINATED BIPHENYL CONGENER NUMBER

Appendix B. Polychlorinated biphenyl congeners from 31 stations in the Millers River Basin, Massachusetts. [Samples are listed in downstream order and correspond in date order to the sample listing in table 2 . When more than one congener is displayed for one bar, multiple IUPAC numbers are given separated by a slash. Unfilled bars represent cases where the ratio of monitored ion molecular fragments recorded by the mass spectrometer did not pass the laboratory-ratio criterion that was established for a congener expected at a particular retention time. Designation (High Res) indicates sample was analyzed additionally by high-resolution mass spectrometry.] - Continued. 


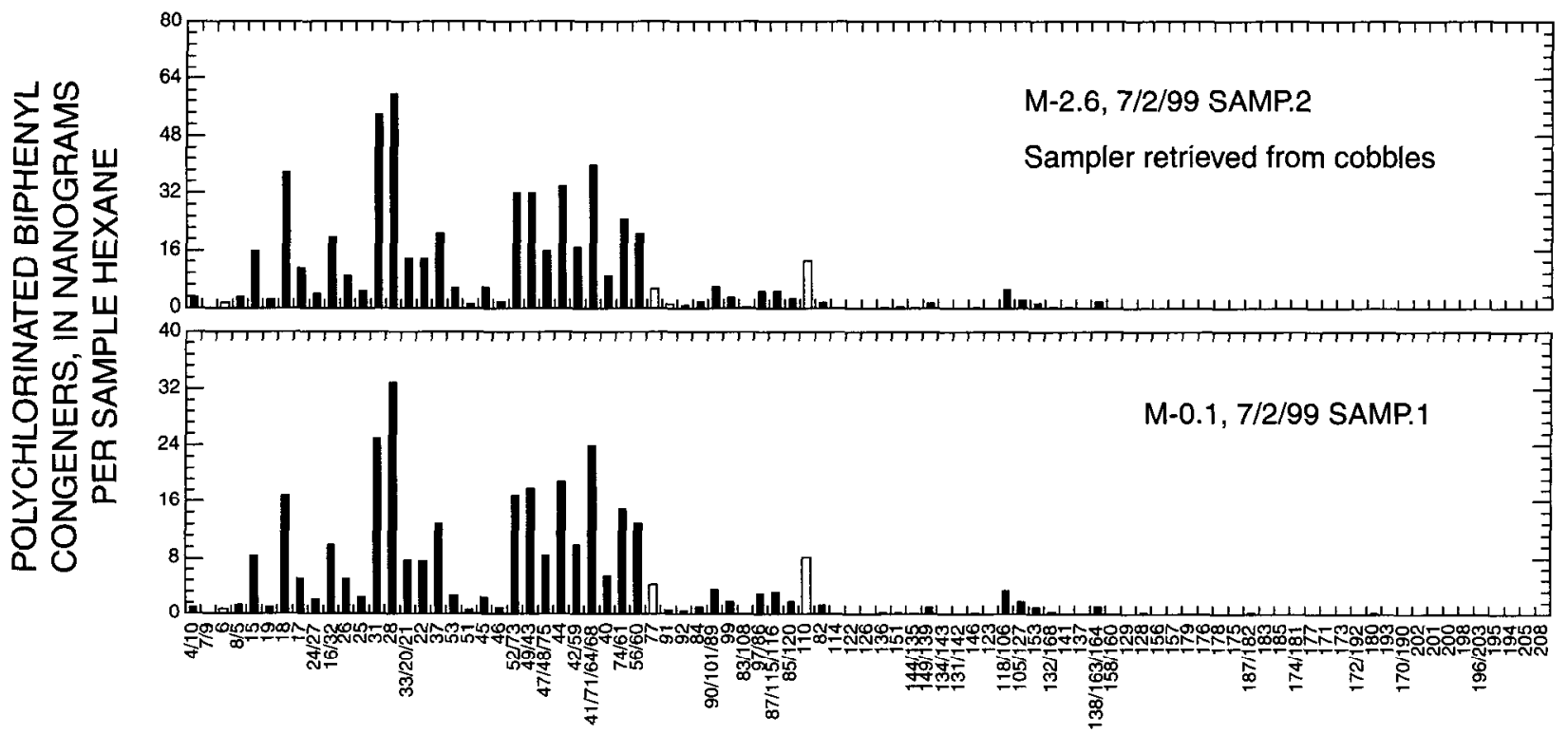

POLYCHLORINATED BIPHENYL CONGENER NUMBER

Appendix B. Polychlorinated biphenyl congeners from 31 stations in the Millers River Basin, Massachusetts. [Samples are listed in downstream order and correspond in date order to the sample listing in table 2. When more than one congener is displayed for one bar, multiple IUPAC numbers are given separated by a slash. Unfilled bars represent cases where the ratio of monitored ion molecular fragments recorded by the mass spectrometer did not pass the laboratory-ratio criterion that was established for a congener expected at a particular retention time. Designation (High Res) indicates sample was analyzed additionally by high-resolution mass spectrometry.] —Continued. 